Z R Research Square

\title{
A 24,482-bp Deletion Increases Seed Weight Through Multiple Pathways in Rapeseed (Brassica Napus L.)
}

\author{
Xiaohui Zhang \\ Huazhong Agriculture University \\ Qiyang Huang \\ Huazhong Agriculture University \\ Pengfei Wang \\ Huazhong Agriculture University \\ Feiyang Liu \\ Huazhong Agriculture University \\ Mudan Luo \\ Huazhong Agriculture University \\ Xiang Li \\ Huazhong Agriculture University \\ Zhuanrong Wang \\ Wuhan Academy of Agricultural Sciences \\ Lili Wan \\ Wuan Academy of Agricultural Sciences \\ Guangsheng Yang \\ Huazhong Agriculture University \\ Dengfeng Hong ( $\sim$ dfhong@mail.hzau.edu.cn ) \\ Huazhong Agricultural University https://orcid.org/0000-0001-9460-219X
}

Research Article

Keywords: fine-mapping, seed weight, transcriptome, cytological, haplotype

Posted Date: February 12th, 2021

DOI: https://doi.org/10.21203/rs.3.rs-189294/v1

License: (c) (i) This work is licensed under a Creative Commons Attribution 4.0 International License. Read Full License 


\section{Abstract}

Exploration of the genes controlling seed weight is critical to improve crop yield and understand the mechanisms underlying seed formation in rapeseed (Brassica napus L.). We previously identified the quantitative trait locus (QTL) qSW.C9, for the thousand-seed weight (TSW) trait, in a double haploid population constructed from $F_{1}$ hybrids between the parental accessions HZ396 and Y106. Here, we confirmed the phenotypic effects associated with $q S W . C 9$ in $\mathrm{BC}_{3} \mathrm{~F}_{2}$ populations and fine-mapped the candidate causal locus to a $266-\mathrm{kb}$ interval. Sequence and expression analyses revealed that a 24,482-bp deletion in HZ396 containing six predicted genes most likely underlies qSW.C9. Differential gene expression analysis and cytological observations suggested that $q S W . C 9$ affects both cell proliferation and cell expansion through multiple signaling pathways. After genotyping a rapeseed diversity panel to define their haplotype structure, we suggest that the selection of germplasm carrying two specific markers may be effective in improving seed weight in rapeseed. This study provides a solid foundation for the identification of the causal gene of $q S W . C 9$ and offers an attractive target for breeding higher-yielding rapeseed.

\section{Key Messages}

we fine-mapped a major QTL for seed weight in rapeseed and a 24,482-bp deletion might be responsible for it through multiple pathways.

\section{Introduction}

Rapeseed (Brassica napus L.) is the second-highest-producing oil crop worldwide (USDA ERS, 2020). Rapeseed provides edible oil for the human diet and is also a promising alternative source of protein for animal feed (Basunanda et al. 2010; Fattahi et al. 2018). Increasing rapeseed yield has long been a primary breeding objective in many countries. It is an especially timely breeding goal in China because of the gradual reduction of arable land and the consequences of rapeseed multiple-purpose development as a means to meet the increasing demand for edible oil (Sun et al. 2018). In rapeseed, yield is determined by the planting density and seed gain per plant, the latter being a reflection of the number of siliques per plant, number of seeds per silique (NSS), and thousand-seed weight (TSW) (Fan et al. 2010). High-density planting is already prevalent in many rapeseed-growing regions, making it relatively challenging to increase yield by modulating the number of siliques per plant or the plant density. However, seed weight and number of seeds per silique are potentially amenable to genetic improvement and thus are promising avenues to explore, which will be accelerated by the characterization of genes associated with seed development.

Quantitative trait locus (QTL) mapping studies for seed weight in rapeseed, using linkage analysis or genome-wide association (Cai et al. 2014; Chen et al. 2007; Fattahi et al. 2018; Fu et al. 2015; Li et al. 2014; Lu et al. 2017), have identified over 168 QTLs regulating seed weight in various populations (Raboanatahiry et al. 2018). Although several QTLs have been fine-mapped to smaller regions (Wang et al. 2020a), only two causal loci have been cloned and shown to influence seed weight: the cytochrome P450 gene BnaA9.CYP78A9 and AUXIN RESPONSE FACTOR18 (ARF18) (Liu et al. 2015; Shi et al. 2019). Along with SUPPRESSOR WITH MORPHOGENETIC EFFECTS ON GENITALIA7 (BnaC9.SMG7b) (Li et al. 2015), which controls the number of seeds per silique, they comprise the short list of genes for yield traits cloned in rapeseed using classical genetics approaches. The many QTLs yet to be cloned represent a vast untapped resource to dissect the mechanisms of seed weight regulation in rapeseed. Given how few genes have been cloned, fine-mapping of important QTLs and cloning their causal genes are particularly critical steps.

Many genes with specific roles in regulating seed size have been cloned in Arabidopsis (Arabidopsis thaliana) and rice (Oryza sativa), among which some have been classified as belonging to major regulatory pathways based on the type of protein they encode or their associated functions (Li et al. 2018; Li et al. 2019b). The close genetic relationship between rapeseed and Arabidopsis can be exploited by characterizing functionally important genes in Arabidopsis and then validating the function of their homologs in rapeseed. This strategy has identified several genes with functions in seed development, although these genes may also affect additional traits. For instance, DA1 encodes an E3 ubiquitin ligase and the mutant da 1-1 results in large seeds in Arabidopsis (Du et al. 2014; Li et al. 2008; Xia et al. 2013). Reduced expression of the rapeseed ortholog BnDA1 can also increase seed size in transgenic rapeseed plants, demonstrating that BnDA1 has the same function in rapeseed as DA1 in Arabidopsis (Wang et al. 2017 ). In addition, ENHANCER OF DA1-1 (EOD3, also known as the cytochrome P450 gene CYP78A6) was identified as an enhancer of the da1-1 mutant and shown to positively regulate seed size in Arabidopsis. The function of the rapeseed homologs was tested via genome editing to inactivate all four EOD3 homologs: the resulting mutant plants showed a reduced thousand-seed weight (TSW) and silique length (SL) and an increased number of seeds per silique (NSS) (Khan et al. 2021). However, no other genes controlling yield-related traits have been characterized in rapeseed, possibly due to differences among Arabidopsis, rice, and rapeseed, whose polyploid genome may hinder the function validation of potential redundancy genes. Thus, it is clear that homology alone is insufficient to identify genes with functions in seed development; however, we reasoned that predictive power may be improved by combining genetics and genomics with transcriptome analysis.

Indeed, gene functions are often determined by their spatial and temporal expression patterns, as seen with genes regulating seed weight (Duan et al. 2017; Liu et al. 2020b; Song et al. 2019). Differential transcriptome analysis has provided new directions of research for the identification of genes involved in a given pathway or process. For example, the rapeseed gene UBIQUITIN-PROTEIN LIGASE3 (BnaUPL3.CO3) regulates seed weight and was discovered by transcriptome association analysis, as its expression is negatively correlated with seed weight. Further analysis showed that BnaUPL3.C03 affects seed weight by mediating the degradation of LEAFY COTYLEDON2 (LEC2), a key transcription factor affecting seed ripening 
(Miller et al. 2019). The identification of BnaUPL3.C03 provides a proof of concept for the identification of functionally important genes by exploiting transcriptomic data as a complementary or alternative approach to traditional map-based cloning and reverse genetics strategies.

We previously reported that the three QTLs $q S S . C 9, q S L . C 9$, and $q S W . C 9$, which respectively affect NSS, silique length, and TSW, are located within the same interval in linkage group (chromosome) C09 (Zhang et al. 2012; Zhang et al. 2011). We later cloned qSS.C9, which is predicted to encode a small protein of 119 amino acids with a key role in the formation of functional megaspores (Li et al. 2015). In this study, we established that $q S W$. C 9 co-segregates with a 24,482-bp deletion removing six predicted genes, two of which encode an E3 ubiquitin ligase and a cytochrome P450 family protein and are likely candidates for the causal locus underlying this QTL. We also characterized the cytological components that associate with seed size and revealed a series of known genes that may be involved in seed size regulation in rapeseed. Finally, haplotype analysis showed that the HZ396 haplotype, representing a germplasm with large seeds, is present at low frequency in a rapeseed diversity panel and may have potential applications in breeding. This study thus lays the foundation for better understanding the mechanism of seed development and provides a new resource to improve rapeseed yield.

\section{Materials And Methods}

\section{Plant materials}

Genetic materials were derived primarily from a cross between the high thousand-seed weight (TSW) inbred line HZ396 (receptor) and the low TSW inbred line Y106 (donor), as previously reported (Li et al. 2015; Zhang et al. 2011). Two $\mathrm{BC}_{3} \mathrm{~F}_{2}$ segregating populations were used to validate the linkage between the TSW phenotype and the qSW.C9 QTL. Recombinant lines screened from the $\mathrm{BC}_{4} \mathrm{~F}_{2}$ population were used for fine-mapping, using the phenotype of their progeny. An NIL (Y106) was randomly selected in the $\mathrm{BC}_{5} \mathrm{~F}_{2}$ population and allowed to self for more than three generations. For most experiments, as well as for sequence and expression analysis, we used the popular inbred line ZS11, whose genome sequence is available (Song et al. 2020).

\section{Plant growth conditions and trait evaluation}

All plant materials were sown at the experimental station of Huazhong Agricultural University during normal growing seasons. Each row consisted of 10-12 plants, with distances of $20 \mathrm{~cm}$ between individuals and $25 \mathrm{~cm}$ between rows. During the growing period, conventional management was conducted according to local planting practices. Two $\mathrm{BC}_{3} \mathrm{~F}_{2}$ populations were sown in autumn 2016 , with 373 and 355 individuals each. During the same growth period, the progeny of 21 recombinant lines were sown in a randomized order, with two rows per line. The two parents and NIL(Y106) were sown and grown over 4 years from 2016 to 2019, with at least six rows sown per germplasm. ZS11 was sown in autumn 2017 and used to sample the seed growth period in the spring of the following year.

For all trait evaluations, individual plants with the same growth status and free of disease were selected for phenotypic analysis. After plants reached maturity, they were air-dried. Ten well-developed pods in the same position about midway along the main stem were used to measure the number of seeds per pod (Zhang et al. 2011). Then, the total number of seeds on the main stem and the first lateral branch were used to measure the thousandseed weight (TSW), by weighing 500-1,000 seeds and then converting the weight into TSW as described (Wang et al. 2020a). Data collection, analysis, and visualization were performed in Microsoft Excel 2016 and GraphPad Prism 8 (https://www.graphpad-prism.cn/).

\section{Genomic DNA extraction and genotyping}

The young leaves or cotyledons were used to extract genomic DNA by a modified CTAB method. Most of the markers used during fine-mapping in this study were sequence-characterized amplified region (SCAR) markers, with the exception of several simple-sequence repeat (SSR) markers, whose names have the prefix "SR." Depending on the marker, products were separated by agarose gel or polyacrylamide gel electrophoresis.

\section{Sequence and candidate gene analysis}

The bacterial artificial chromosome (BAC) clone HBnB016G24 was re-sequenced by next-generation sequencing (NGS) to provide a precise reference. The databases BRAD (http://brassicadb.org/brad/index.php), BnPIR (http://cbi.hzau.edu.cn/bnapus/index.php), and Genoscope (http://www.genoscope.cns.fr/brassicanapus/) provided reference sequences and information about predicted genes. For more detailed genetic information, the databases BnTIR (http://yanglab.hzau.edu.cn/BnTIR), TAIR (https://www.arabidopsis.org/), and NCBI (https://www.ncbi.nlm.nih.gov/) were used.

The software Geneious 4.8.3 was used for sequence analysis and alignments. IGV 2.8.6 (http://www.igv.org/) was used to visualize the reads generated by NGS. IBS 1.0.3 (http://ibs.biocuckoo.org/) was used to draw the sketch maps of gene distributions.

\section{Total RNA extraction and RT-qPCR analysis}

For expression analysis, samples were obtained from ZS11 at nine stages of seed development and subjected to RNA-seq analysis. The nine stages were as follows: 0-6 mm pistils, 1 DAP (days after pollination) pistils, 3 DAP pistils, 6 DAP seeds, 15 DAP seeds, 21 DAP seeds, 28 DAP seeds, 38 DAP seeds, and 50 DAP seeds. Seeds at 15 DAP from the inbred lines HZ396 and NIL(Y106) were also harvested and analyzed by RNA-seq and RT-

Page 3/22 
qPCR. Plant tissues were harvested in a nuclease-free environment, quickly frozen in liquid nitrogen, and then stored at $-80^{\circ} \mathrm{C}$. Total RNA was

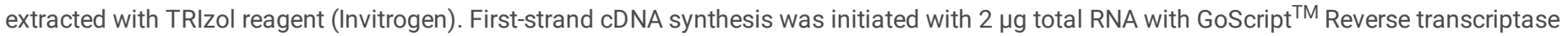
(Promega, USA). qPCR was performed with the GoTaq qPCR Mix (Promega, USA) on a Bio-Rad CFX96 Real-time System (Bio-Rad). The $2^{-\Delta \triangle C t}$ method was employed to calculate the relative expression levels of genes of interest based on three biological samples and three technical replicates per sample (Livak and Schmittgen 2001). BnACTIN2 (BnaC03G0430900ZS) was used as the internal control for normalization. Data collection, analysis, and visualization were performed in Microsoft Excel 2016 and GraphPad Prism 8.

\section{Transcriptome analysis}

Transcriptome deep sequencing (RNA-seq) was performed on an Illumina HiSeq platform with three biological replicates per sample. Gene expression levels are reported as trimmed means of $M$-values (TMM). To screen for differentially expressed genes (DEGs), Rsubread (DOI: 10.18129/B9.bioc.Rsubread) was used to count the reads associated with each gene to generate an input file compatible with DESeq2 (DOI: 10.18129/B9.bioc.DESeq2) for differential expression analysis. An adjusted $p$-value $<0.05$ and an absolute value of log 2 ratio $>1$ were applied as thresholds to select DEGs. Gene Ontology (GO) enrichment analysis was performed with clusterProfiler (DOI: 10.18129/B9.bioc.clusterProfiler).

\section{Cytological observations and analysis}

Mature dry seeds of HZ396 and NIL(Y106) were germinated on wet absorbent paper. The hypocotyls of 10-day-old seedlings were fixed and embedded in paraffin to visualize cells in cross sections after toluidine blue staining. Slices were observed on a Nikon Eclipse E100 microscope and images collected with CaseViewer (https://www.3dhistech.com/). ImageJ (https://imagej.net/Welcome) was then used to count the number of cells and measure their corresponding area. For each line, data from six or seven separate slices were collected for analysis.

The epidermal cells of mature dry seeds of HZ396 and NIL(Y106) were observed by scanning electron microscopy (SEM). The images were collected at 400x magnification; ImageJ was then used to count the number of cells and measure their corresponding area. Nine separate seeds were selected from each material for observation and statistical analysis. Data collection, analysis, and visualization were performed in Microsoft Excel 2016 and GraphPad Prism 8.

\section{Haplotype analysis}

A diversity panel of 505 inbred lines was used for haplotype analysis with three years of phenotypic data on TSW (Tang et al. 2020). Genomic DNA from these lines was used as a template to genotype the SCAR markers XH14 and STC9-164 by agarose gel electrophoresis. The XH14 marker is dominant and is therefore scored as presence or absence. The STC9-164 marker results in two bands during amplification, with the smaller band being used to determine the genotype. The combination of these two markers defined four haplotypes. One-way ANOVA was performed to determine statistical significance of the differences for TSW between the HZ396 haplotype and the other haplotypes. Data collection, analysis, and visualization were performed in Microsoft Excel 2016 and GraphPad Prism 8.

\section{Results}

\section{qSW.C 9 behaves as a single locus in the $\mathrm{BC}_{3} \mathrm{~F}_{2}$ population}

To verify the function of $q S W . C 9$, we generated and phenotyped two $\mathrm{BC}_{3} \mathrm{~F}_{2}$ populations derived from a cross between the inbred lines $\mathrm{HZ396}$ and Y106, with 203 (group A) and 157 (group B) effective individuals. The parents exhibited a significant difference of TSW, with a value of $4.91 \pm 0.39 \mathrm{~g}$ for HZ396 and $3.56 \pm 0.19 \mathrm{~g}$ for Y106 (Fig. 1a, b). TSW values from group A ranged from 2.66 to $4.92 \mathrm{~g}$; a chi-squared test demonstrated that the low TSW phenotype segregated in a Mendelian fashion, as the segregation ratio was 3:1 (Table. S1). The TSW phenotype co-segregated with the codominant marker SCC9-136 and the dominant marker STC9-164 in group A (Fig. 1C, e). In addition, plants heterozygous or homozygous for the Y106 allele at these two markers displayed similar and low TSW values (Fig. 1d, f), results that were recapitulated in group B (Fig. S1). These results indicated that qSW.C9 is closely linked to markers SCC9-136 and STC9-164 and that the HZ396 allele at this QTL behaves as a single dominant gene that regulates rapeseed TSW.

\section{Fine-mapping of $q S W . C 9$}

To fine-map the qSW.C9 QTL and clone the underlying locus, we characterized 19 recombinant lines in the $\mathrm{BC}_{3} \mathrm{~F}_{2}$ population with the high $\mathrm{TSW}$ phenotype with markers SCC9-136 and SRC9-21 (Fig. S2). We then genotyped 21 representative recombinants between the same markers with seven markers spanning the interval and also determined TSW values of their progeny $\left(\mathrm{BC}_{4} \mathrm{~F}_{3}\right.$ population) in 2017. Based on these data, we narrowed down the mapping interval to between markers SRC9-298 and SRC9-397. The size of the corresponding genomic region is about $261 \mathrm{~kb}$ in the rapeseed Damor-bzh reference genome but appears to be $310 \mathrm{~kb}$ in the ZS11 reference genome, which is of better quality. To gain a more accurate genomic sequence for the interval, we sequenced the BAC clone HBnB016G24 and compared the aligned sequence to the ZS11 reference genome in 150-kb fragments: sequence identity was as high as $99.9 \%$ (Fig. S3a). With this new reference sequence, we designed two linked simple-sequence repeat (SSR) markers (XHSRC9-69 and XHSRC9-52) and a single-nucleotide polymorphism (SNP) marker (SNP5479) between STC9-298 and SRC9-397 (Fig. 2a). Although we genotyped 118 individuals with the two SSR markers, we did not identify any new recombination break points. We also genotyped 
21 recombinant lines with SNP5479 (Fig. S4), allowing us to anchor the mapping interval to between markers SNP5479 and SRC9-397 (Fig. 2b), or a 266-kb genomic fragment in the ZS11 genome.

\section{Analysis of genes within the mapping interval}

The 266-kb region contained 39 genes in the ZS11 reference genome (Fig. 2c), including several sets of duplicated or triplicated homologous genes. To explore the genomic differences between the HZ396 and Y106 parental lines, we sequenced the HZ396 and Y106 genomes, assembled the reads over the mapping interval, and compared the assembly to ZS11. The Y106 genomic sequence over the mapping interval was largely congruent with that of ZS11, whereas HZ396 carried a large deletion, in addition to other variations (Fig. S3b). To determine the size and delineate the break points of the deletion in the HZ396 background, we designed PCR primers annealing to either side of the presumptive deletion interval. One primer pair amplified a 5-kb fragment specifically in HZ396, but not in Y106, as the predicted size of the PCR product in this genotype would be over $25 \mathrm{~kb}$ (Fig. S3c). This 5-kb fragment from HZ396 aligned perfectly to the ZS11 reference but also revealed a deletion of 24,482 bp (Fig. 2d and Fig. S3d). We validated the size and position of the deletion by using a set of nine specific markers spanning the deletion interval (Fig. S3e). Outside the deletion, resequencing data for $\mathrm{HZ396,} \mathrm{Y106,} \mathrm{and} \mathrm{NIL}(\mathrm{Y} 106)$ showed no genomic variation in the coding regions of the 33 genes present in the 266-kb interval, with the exception of BnaC09G0547900ZS and BnaC09G0548700ZS. BnaC09G0547900ZS had one SNP in the exon that leads to a synonymous mutation, while BnaC09G0548700ZS carried an SNP in an intron (Table. 1). This result indicated that there were no differences between HZ396 and Y106 in regard to protein-coding genes in the mapping interval aside from those included in the deletion.

We then turned to transcriptome deep sequencing (RNA-seq) to measure expression levels of candidate genes by collecting samples for nine stages of seed development from ZS11 plants. Surprisingly, only 26 genes were expressed during seed development, while the remaining 13 genes were not expressed at any stage and are therefore unlikely to be the causal gene for qSW.C9 (Fig. S5). 15 DAP appeared to be a useful sampling time point, as more genes within the mapping interval were expressed then than at any other stage. We therefore focused on RNA-seq data from HZ396 and NIL(Y106) seeds at 15 DAP. Compared to NIL(Y106), 424 genes were significantly upregulated in HZ396, with the other 609 genes that were significantly downregulated (Fig. S5a). We validated the RNA-seq data for 15 randomly selected DEGs by RT-qPCR, confirming the reliability of our RNA-seq results (Fig. S5b). None of the genes within the mapping interval showed significant differences in expression between HZ396 and NIL(Y106) (Table.1 and Fig. S5c), pointing to the 24,482-bp deletion and the six corresponding genes as most likely to be causal for qSW.C9.

Within the deletion interval, two genes caught our attention. BnaC09G0551200ZS encodes a cytochrome P450 protein (CYP81K2), whose function is not known. Notably, many cytochrome P450 genes regulate seed size and yield in Arabidopsis and other crops (Eriksson et al. 2010; Fang et al. 2012; Khan et al. 2021; Shi et al. 2019; Xu et al. 2015; Zhao et al. 2016). In addition, CYP81K2 is the only gene with no nearby homolog within the mapping interval, making it a prime candidate for qSW.C9. The gene pair, BnaC09G0551500ZS and BnaC09G0551600ZS (described as

BnaC09G0551500ZS/BnaC09G0551600ZS), together encode a RING-type E3 ubiquitin ligase that is homologous to Arabidopsis JAV1-ASSOCIATED UBIQUITIN LIGASE1 (JUL1). JUL1 is reported to be involved in abscisic acid (ABA) and jasmonic acid (JA) signaling, especially during abiotic stress (Ali et al. 2019; Yu et al. 2020a). This is consistent with SALT- AND DROUGHT-INDUCED REALLY INTERESTING NEW GENE FINGER1 (SDIR1), a gene related to seed weight in wheat (Triticum aestivum) (Wang et al. 2020b, Gao et al. 2011; Liu et al. 2013; Zhang et al. 2008).

\section{qSW.C9 controls seed size through multiple signal pathways}

To determine the molecular mechanism(s) by which qSW.C9 regulates seed size, we subjected the DEGs between HZ396 and NIL(Y106) to Gene Ontology (GO) analysis. This analysis revealed 95 enriched GO terms across the three categories biological processes (BP), cellular compartment (CC), and molecular function (MF) (Table S2). Most enriched GO terms were related to ion homeostasis and transmembrane transport. The constituent genes were associated with well-known pathways that regulate seed size or yield: sucrose transport, cytochrome P450 genes, and leucine-rich repeat (LRR)-related genes (Fig. 3a). We validated the RNA-seq results by RT-qPCR for nine genes related to seed size (Fig. 3b).

The GO analysis and DEGs allowed us to create a list of genes that may be involved in the regulation of seed weight in rapeseed. This list included several published genes linked to seed size, yield, and fruit size, as well as others probably encoding seed size regulatory factors, such as proteins involved in cell division and expansion, transcription factors, phytohormone signaling proteins, and transporters (Table 2). This analysis suggested that the difference in seed size between $\mathrm{HZ396}$ and $\mathrm{NIL}(\mathrm{Y} 106)$ may be regulated by multiple signaling pathways.

\section{qSW.C9 controls seed size by regulating both cell expansion and proliferation}

Seed size may be regulated by cell expansion, cell proliferation, or both. To gain a cellular-level understanding of the difference in seed size between HZ396 and NIL(Y106) (Fig. 4a, c), we examined cells from the seed coat of mature HZ396 and NIL (Y106) seeds by scanning electron microscopy (SEM). In addition to a difference in cell morphology, the cells also showed a slight but significant difference in size between HZ396 and NIL (Y106), as determined by their surface (Fig. 4b, d). In addition, the cell number in HZ396 was $34.2 \%$ greater than in NIL(Y106), while the cell size was $7.8 \%$ greater than in NIL(Y106) (Table. S3). These results suggested that qSW.C9 regulates both cell number and cell size. We extended our analysis to paraffin cross sections of hypocotyls (Fig. 4e). Again, we observed significant differences in the number of cells in the epidermis and the inner three layers of the hypocotyl (Fig. 4f), as well as in the size of cells (Fig. 4g). These results indicated that qSW.C9 probably controls seed size by regulating both cell expansion and proliferation. 
To explore the effect of $q S W . C 9$ in natural populations, we collected 505 accessions with TSW data and determined their genotype at $q S W$.C9 using the specific markers XH14 and STC9-164. XH14 is a marker designed to amplify BnaC09G0551500ZS/BnaC09G0551600ZS, while STC9-164 is specific for BnaC09G0551300ZS (Fig. S6). Both markers are dominant, as they will either amplify the gene (as in Y106) or yield no amplicon (as in HZ396). These two markers will broadly classify our collection into four possible haplotypes at or near qSW.C9 (Fig. 5a). Haplotype A (positive for both markers, like Y106) consisted of 478 accessions; their TSW values varied from 1.95 to $5.46 \mathrm{~g}$, with a mean of $3.47 \mathrm{~g}$. Haplotype D (negative for both markers, like HZ396) consisted of 12 accessions, with TSW values ranging from 2.16 to $4.42 \mathrm{~g}$ and a mean of $3.59 \mathrm{~g}$. Haplotype B (positive for STC9-164 only) comprised 12 accessions; the TSW values varied from 2.59 to $3.64 \mathrm{~g}$ with a mean of $3.14 \mathrm{~g}$. We identified no germplasm with haplotype C. Although mean TSW across haplotype D increased by $0.12 \mathrm{~g}$ over that of haplotype A, this difference was not significant, as determined by one-way ANOVA. By contrast, mean TSW for haplotype D was significantly higher than that in haplotype B, as mean TSW increased by $0.45 \mathrm{~g}$ (Fig. $5 b)$. These results indicated that haplotype $D$ is a rare haplotype that offers the largest TSW values, which will be of great potential use to improve seed weight in rapeseed. The genotyping markers XH14 and STC9-164 will provide an effective means to select haplotype D during the breeding process.

\section{Discussion}

We previously showed that the QTL for the TSW trait qSW.C9 co-located with the QTL qSS.C9 for NSS using linkage analysis in a double haploid population (Zhang et al. 2012). We later cloned the causal gene for qSS.C9, BnaC9.SMG7b (Li et al. 2015). Here, we fine-mapped qSW.C9 to a 266-kb region on chromosome $\mathrm{C} 09$ and discovered a 24,482-bp deletion that is likely responsible for $q S W$. C9. Notably, this mapping interval contains BnaC9.SMG7b, indicating the strong linkage between TSW and NSS. Though the co-segregation of the TSW and NSS phenotypes also raises a conundrum regarding whether BnaC9.SMG7b regulates both NSS and TSW, giving rise to more seeds per silique but with small size, we think it more likely that QSW.C9 corresponds to a candidate gene other than BnaC9.SMG7b itself for two reasons. First, when considering the co-regulation between yield-related traits, SL and NSS are generally regulated in the same direction, whereas the relationship between TSW and NSS is not always consistent (Hussain et al. 2020). Second, no seed size-related phenotypes have been reported in smg7mutants (Bulankova et al. 2010; Kerenyi et al. 2013; Lee et al. 2020; Raxwal et al. 2020; Riehs-Kearnan et al. 2012).

Aside from BnaC9.SMG7b, there are five other candidate genes in the 24,482-bp deletion region. In Arabidopsis and other crops, there are no reports clearly showing any of these genes to be related to yield traits. However, the E3 ubiquitin ligase encoded by BnaC09G0551500ZS/BnaC09G0551600ZS also warrants some attention. The ubiquitin-proteasome system plays an essential role in almost all aspects of biology (Moon et al. 2004). Notably, a related pathway controlling seed size has already been established in Arabidopsis and rice (Li and Li 2014; Xu and Xue 2019). RING-type E3 ligases, such as Arabidopsis DA2 and rice Grain Width2 (GW2), play an important role in regulating seed size; their homologs in wheat (Triticum aestivum) and maize (Zea mays) appear to have the same function (Lee et al. 2018; Sestili et al. 2019; Simmonds et al. 2016; Wang et al. 2018; Xie et al. 2018; Zhang et al. 2018; Zhao et al. 2015). Here, BnaC09G0551500ZS/BnaC09G0551600ZS encode a RING-type E3 ubiquitin ligase that is homologous to Arabidopsis JUL, which has reported roles in abiotic stress, ABA, and JA signaling (Ali et al. 2019; Yu et al. 2020a). Notably, the wheat homolog of the RING-type E3 ligase-encoding Arabidopsis gene SALT-AND DROUGHT-INDUCED REALLY INTERESTING NEW GENE FINGER1 (SDIR1) is a negative regulator of seed size (Wang et al. 2020b), while SDIR1 is reported to be involved in salt tolerance and drought resistance (Gao et al. 2011; Liu et al. 2013; Zhang et al. 2008). This observation supports the hypothesis that BnaC09G0551500ZS/BnaC09G0551600ZS might be causal for qSW.C9.

Because the seed coat determines the space available for the embryo and endosperm to develop, seed size is usually affected by the seed coat (Li et al. 2019b). Examining seed coat cells will therefore help us better understand seed formation. SEM has been effectively applied in Arabidopsis and many crops to reveal the morphology of cells at the surface of the seed coat (Huang et al. 2017; Lyu et al. 2020; Xu et al. 2018; Yang et al. 2019). Although SEM has been used to observe rapeseed silique epidermal cells (Shi et al. 2019), the direct observation of cells from the seed coat is typically carried out via serial sectioning ( $\mathrm{Li}$ et al. 2019a). We demonstrated here that SEM can provide a detailed view of seed coat cells. We observed significant differences in cell size and number between the parental line HZ396 and NIL(Y106), indicating that qSW.C9 regulates both cell proliferation and cell expansion. Most genes regulate seed size by affecting either cell division or cell expansion, but rarely both; examples include Arabidopsis EOD3 (Fang et al. 2012), rice Grain Size5 (GS5) (Li et al. 2011), and rice DENSE AND ERECT PANICLE2 (DEP2) (Abe et al. 2010). We observed that the expression of BnEOD3 in NIL(Y106) is six times higher than in HZ396, indicating that the germplasm with low BnEOD3 expression also exhibited larger seeds, which is not consistent with the reported phenotypes associated with loss of EOD3 in Arabidopsis or rapeseed (Khan et al. 2021). This difference suggests that BnEOD3 may regulate cell proliferation and cell expansion through a novel regulatory mechanism in our materials.

We identified several previously reported genes regulating seed size among our DEGs. Some, such as CYP78A5/KLU(Eriksson et al. 2010), SUCROSEPROTON SYMPORTER2 (SUC2) (Wang et al. 2015), and JASMONATE METHYL TRANSFERASE (JMT) (Kim et al. 2009), had homologs in Arabidopsis whose functions are opposite to those reported here. However, the expression of the rapeseed homologs of HISTIDINE PHOSPHOTRANSFER PROTEIN4 (AHP4) (Hutchison et al. 2006) and C-TERMINALLY ENCODED PEPTIDE RECEPTOR1 (CEPR1, also named XYLEM INTERMIXED WITH PHLOEM1 [XIP1]) (Taleski et al. 2020) was consistent with the functions reported in Arabidopsis. The mechanism underlying the regulation of seed 
weight and size may thus be more complex in rapeseed than in Arabidopsis, but our RNA-seq and GO analyses have provided new directions to help dissect this critical regulatory network.

As the qSW.C9 QTL was associated with yield, we aimed to develop genotyping markers that might be useful for marker-assisted breeding by screening germplasm resources. Although a single marker often is sufficient to distinguish different genotypes, in other cases multiple markers may be necessary to identify favorable alleles (Liu et al. 2020a; Wang et al. 2020b). Here, we identified a 24,482-bp deletion in HZ396 compared to Y106 and developed two specific markers for the deletion region. We then identified rapeseed accessions with the HZ396 haplotype (PCR-negative for both markers) and observed that this rare haplotype was associated with the highest TSW values. Thus, our identification of the qSW.C9 QTL should have considerable utility for future rapeseed breeding and improvement.

\section{Declarations}

\section{Author Contributions}

XZ conducted most experiments, including fine-mapping, sequence analysis, cytological observations, and haplotype analysis. QH and FL participated in phenotypic and genotypic analyses of $\mathrm{BC}_{3} \mathrm{~F}_{2}$ populations and recombinant lines. $\mathrm{ML}$ and $\mathrm{XL}$ participated in sequence analysis. $\mathrm{PW}$ participated in RNA-seq data analysis. XZ wrote the original draft. ZW, LW, and DH were involved in reviewing and editing the manuscript. DH and GY designed and supervised the project. All authors read and contributed to the revision of manuscript.

\section{Acknowledgements}

This study was supported by National Natural Science Foundation of China (32072099), Natural Science Foundation of Hubei (2019CFA090), and Wuhan Applied Foundational Frontier Project (2019020701011446). We thank Prof. Dr. Liang Guo for providing the thousand-seed weight phenotype of a rapeseed diversity panel. We declare that we have no conflict of interest.

\section{References}

Abe Y, Mieda K, Ando T, Kono I, Yano M, Kitano H, Iwasaki Y(2010) The SMALL AND ROUND SEED1 (SRS1/DEP2) gene is involved in the regulation of seed size in rice. Genes Genet Syst 85:327-339

Ali MRM, Uemura T, Ramadan A, Adachi K, Nemoto K, Nozawa A, Hoshino R, Abe H, Sawasaki T, Arimura GI (2019) The Ring-Type E3 Ubiquitin Ligase JUL1 Targets the VQ-Motif Protein JAV1 to Coordinate Jasmonate Signaling. Plant Physiol 179:1273-1284

Bashandy T, Meyer Y, Reichheld JP (2011) Redox regulation of auxin signaling and plant development in Arabidopsis. Plant Signal Behav 6:117-119

Basunanda P, Radoev M, Ecke W, Friedt W, Becker HC, Snowdon RJ (2010) Comparative mapping of quantitative trait loci involved in heterosis for seedling and yield traits in oilseed rape (Brassica napus L.). Theor Appl Genet 120:271-281

Besnard J, Zhao C, Avice JC, Vitha S, Hyodo A, Pilot G, Okumoto S (2018) Arabidopsis UMAMIT24 and 25 are amino acid exporters involved in seed loading. J Exp Bot 69:5221-5232

Bulankova P, Akimcheva S, Fellner N, Riha K (2013) Identification of Arabidopsis meiotic cyclins reveals functional diversification among plant cyclin genes. PLoS Genet 9:e1003508

Bulankova P, Riehs-Kearnan N, Nowack MK, Schnittger A, Riha K (2010) Meiotic progression in Arabidopsis is governed by complex regulatory interactions between SMG7, TDM1, and the meiosis I-specific cyclin TAM. Plant Cell 22:3791-3803

Cai D, Xiao Y, Yang W, Ye W, Wang B, Younas M, Wu J, Liu K (2014) Association mapping of six yieldrelated traits in rapeseed (Brassica napus L.). Theor Appl Genet 127:85-96

Carvalho SD, Chatterjee M, Coleman L, Clancy MA, Folta KM (2016) Analysis of Block of cell proliferation 1 (BOP1) activity in strawberry and Arabidopsis. Plant Sci 245:84-93

Chen LQ, Lin IW, Qu XQ, Sosso D, McFarlane HE, Londono A, Samuels AL, Frommer WB (2015) A cascade of sequentially expressed sucrose transporters in the seed coat and endosperm provides nutrition for the Arabidopsis embryo. Plant Cell 27:607-619

Chen W, Zhang Y, Liu X, Chen B, Tu J, Tingdong F (2007) Detection of QTL for six yield-related traits in oilseed rape (Brassica napus) using DH and immortalized $F_{2}$ populations. Theor Appl Genet 115:849-858

Chen Y, Sun S, Wang X (2020) The epidermis-specific cyclin CYCP3;1 is involved in the excess brassinosteroid signaling-inhibited root meristem cell division. J Integr Plant Biol 62:1674-1687

Page $7 / 22$ 
Cipollini D (2007) Consequences of the overproduction of methyl jasmonate on seed production, tolerance to defoliation and competitive effect and response of Arabidopsis thaliana. New Phytol 173:146-153

Cucinotta M, Cavalleri A, Guazzotti A, Astori C, Manrique S, Bombarely A, Oliveto S, Biffo S, Weijers D, Kater MM, Colombo L (2020) Alternative Splicing Generates a MONOPTEROS Isoform Required for Ovule Development. Current Biology 31:1-8

Darnet S, Martin LBB, Mercier P, Bracher F, Geoffroy P, Schaller H (2020) Inhibition of Phytosterol Biosynthesis by Azasterols. Molecules 25:1111

DeYoung BJ, Bickle KL, Schrage KJ, Muskett P, Patel K, Clark SE (2006) The CLAVATA1-related BAM1, BAM2 and BAM3 receptor kinase-like proteins are required for meristem function in Arabidopsis. Plant $\mathrm{J}$ 45:1-16

Du L, Li N, Chen L, Xu Y, Li Y, Zhang Y, Li C, Li Y (2014) The ubiquitin receptor DA1 regulates seed and organ size by modulating the stability of the ubiquitin-specific protease UBP15/SOD2 in Arabidopsis. Plant Cell 26:665-677

Duan P, Xu J, Zeng D, Zhang B, Geng M, Zhang G, Huang K, Huang L, Xu R, Ge S, Qian Q, Li Y (2017) Natural Variation in the Promoter of GSE5 Contributes to Grain Size Diversity in Rice. Mol Plant 10:685-694

Eriksson S, Stransfeld L, Adamski NM, Breuninger H, Lenhard M (2010) KLUH/CYP78A5-dependent growth signaling coordinates floral organ growth in Arabidopsis. Curr Biol 20:527-532

Etchells JP, Provost CM, Turner SR (2012) Plant vascular cell division is maintained by an interaction between PXY and ethylene signalling. PLoS Genet 8:e1002997

Fan C, Cai G, Qin J, Li Q, Yang M, Wu J, Fu T, Liu K, Zhou Y (2010) Mapping of quantitative trait loci and development of allele-specific markers for seed weight in Brassica napus. Theor Appl Genet 121:1289-1301

Fang W, Wang Z, Cui R, Li J, Li Y (2012) Maternal control of seed size by EOD3/CYP78A6 in Arabidopsis thaliana. Plant J 70:929-939

Fattahi F, Fakheri BA, Solouki M, Möllers C, Rezaizad A (2018) Mapping QTL controlling agronomic traits in a doubled haploid population of winter oilseed rape (Brassica napus L.). Journal of Genetics 97:1389-1406

Fu Y, Wei D, Dong H, He Y, Cui Y, Mei J, Wan H, Li J, Snowdon R, Friedt W, Li X, Qian W (2015) Comparative quantitative trait loci for silique length and seed weight in Brassica napus. Scientific Reports 5:14407

Gao T, Wu Y, Zhang Y, Liu L, Ning Y, Wang D, Tong H, Chen S, Chu C, Xie Q (2011) OsSDIR1 overexpression greatly improves drought tolerance in transgenic rice. Plant Mol Biol 76:145-156

Huang K, Wang D, Duan P, Zhang B, Xu R, Li N, Li Y (2017) WIDE AND THICK GRAIN 1, which encodes an otubain-like protease with deubiquitination activity, influences grain size and shape in rice. Plant J 91:849-860

Hussain Q, Shi J, Scheben A, Zhan J, Wang X, Liu G, Yan G, King GJ, Edwards D, Wang H (2020) Genetic and signalling pathways of dry fruit size: targets for genome editing-based crop improvement. Plant Biotechnol J 18:1124-1140

Hutchison CE, Li J, Argueso C, Gonzalez M, Lee E, Lewis MW, Maxwell BB, Perdue TD, Schaller GE, Alonso JM, Ecker JR, Kieber JJ (2006) The Arabidopsis histidine phosphotransfer proteins are redundant positive regulators of cytokinin signaling. Plant Cell 18:3073-3087

Huysmans M, Buono RA, Skorzinski N, Radio MC, De Winter F, Parizot B, Mertens J, Karimi M, Fendrych M, Nowack MK (2018) NAC Transcription Factors ANAC087 and ANAC046 Control Distinct Aspects of Programmed Cell Death in the Arabidopsis Columella and Lateral Root Cap. Plant Cell 30:2197-2213

Jha AK, Wang Y, Hercyk BS, Shin HS, Chen R, Yang M (2014) The role for CYCLIN A1;2/TARDY ASYNCHRONOUS MEIOSIS in differentiated cells in Arabidopsis. Plant Mol Biol 85:81-94

Kerenyi F, Wawer I, Sikorski PJ, Kufel J, Silhavy D (2013) Phosphorylation of the N-and C-terminal UPF1 domains plays a critical role in plant nonsense-mediated mRNA decay. Plant J 76:836-848

Kanno Y, Oikawa T, Chiba Y, Ishimaru Y, Shimizu T, Sano N, Koshiba T, Kamiya Y, Ueda M, Seo M (2016) AtSWEET13 and AtSWEET14 regulate gibberellin-mediated physiological processes. Nat Commun 7:13245

Kathare PK, Dharmasiri S, Dharmasiri N (2018) SAUR53 regulates organ elongation and apical hook development in Arabidopsis. Plant Signal Behav 13:e1514896

Khan MHU, Hu L, Zhu M, Zhai Y, Khan SU, Ahmar S, Amoo O, Zhang K, Fan C, Zhou Y (2021) Targeted mutagenesis of EOD3 gene in Brassica napus L. regulates seed production. J Cell Physiol 236:1996-2007 
Kim EH, Kim YS, Park SH, Koo YJ, Choi YD, Chung YY, Lee IJ, Kim JK (2009) Methyl jasmonate reduces grain yield by mediating stress signals to alter spikelet development in rice. Plant Physiol 149:1751-1760

Lee BH, Kwon SH, Lee SJ, Park SK, Song JT, Lee S, Lee MM, Hwang YS, Kim JH (2015) The Arabidopsis thaliana NGATHA transcription factors negatively regulate cell proliferation of lateral organs. Plant Mol Biol 89:529-538

Lee KH, Park SW, Kim YJ, Koo YJ, Song JT, Seo HS (2018) Grain width 2 (GW2) and its interacting proteins regulate seed development in rice (Oryza sativa L.). Bot Stud 59:23

Lee WC, Hou BH, Hou CY, Tsao SM, Kao P, Chen HM (2020) Widespread Exon Junction Complex Footprints in the RNA Degradome Mark mRNA Degradation before Steady State Translation. Plant Cell 32:904-922

Li F, Chen B, Xu K, Wu J, Song W, Bancroft I, Harper AL, Trick M, Liu S, Gao G, Wang N, Yan G, Qiao J, Li J, Li H, Xiao X, Zhang T, Wu X (2014) Genomewide association study dissects the genetic architecture of seed weight and seed quality in rapeseed (Brassica napus L.). DNA Res 21:355-367

Li N, Li Y (2014) Ubiquitin-mediated control of seed size in plants. Front Plant Sci 5:332

Li N, Song D, Peng W, Zhan J, Shi J, Wang X, Liu G, Wang H (2019a) Maternal control of seed weight in rapeseed (Brassica napus L.): the causal link between the size of pod (mother, source) and seed (offspring, sink). Plant Biotechnol J 17:736-749

Li N, Xu R, Duan P, Li Y (2018) Control of grain size in rice. Plant Reprod 31:237-251

Li N, Xu R, Li Y (2019b) Molecular Networks of Seed Size Control in Plants. Annu Rev Plant Biol 70:435-463

Li S, Chen L, Zhang L, Li X, Liu Y, Wu Z, Dong F, Wan L, Liu K, Hong D, Yang G (2015) BnaC9.SMG7b functions as a positive regulator of number of seeds per silique in rapeseed (Brassica napus L.) by regulating the formation of functional female gametophytes. Plant Physiology 169:2744-2760

Li Y, Fan C, Xing Y, Jiang Y, Luo L, Sun L, Shao D, Xu C, Li X, Xiao J, He Y, Zhang Q (2011) Natural variation in GS5 plays an important role in regulating grain size and yield in rice. Nat Genet 43:1266-1269

Li Y, Zheng L, Corke F, Smith C, Bevan MW (2008) Control of final seed and organ size by the DA1 gene family in Arabidopsis thaliana. Genes Dev 22:1331-1336

Liao S, Wang L, Li J, Ruan YL (2020) Cell Wall Invertase Is Essential for Ovule Development through Sugar Signaling Rather Than Provision of Carbon Nutrients. Plant Physiol 183:1126-1144

Liu J, Hua W, Hu Z, Yang H, Zhang L, Li R, Deng L, Sun X, Wang X, Wang H (2015) Natural variation in ARF18 gene simultaneously affects seed weight and silique length in polyploid rapeseed. Proc Natl Acad Sci 112:E5123-E5132

Liu J, Xia Z, Wang M, Zhang X, Yang T, Wu J (2013) Overexpression of a maize E3 ubiquitin ligase gene enhances drought tolerance through regulating stomatal aperture and antioxidant system in transgenic tobacco. Plant Physiol Biochem 73:114-120

Liu Y, Zhou X, Yan M, Wang P, Wang H, Xin Q, Yang L, Hong D, Yang G (2020a) Fine mapping and candidate gene analysis of a seed glucosinolate content QTL, qGSL-C2, in rapeseed (Brassica napus L.). Theor Appl Genet 133:479-490

Liu Z, Li N, Zhang Y, Li Y (2020b) Transcriptional repression of GIF1 by the KIX-PPD-MYC repressor complex controls seed size in Arabidopsis. Nat Commun 11:1846

Livak KJ, Schmittgen TD (2001) Analysis of relative gene expression data using real-time quantitative PCR and the $2^{-\triangle \Delta C} \mathrm{~T}_{\mathrm{T}} \mathrm{Pethod}^{\mathrm{A}} \mathrm{Methods} 25: 402-$ 408

Lu K, Peng L, Zhang C, Lu J, Yang B, Xiao Z, Liang Y, Xu X, Qu C, Zhang K, Liu L, Zhu Q, Fu M, Yuan X, Li J (2017) Genome-Wide Association and Transcriptome Analyses Reveal Candidate Genes Underlying Yield-determining Traits in Brassica napus. Front Plant Sci 8:206

Lyu J, Wang D, Duan P, Liu Y, Huang K, Zeng D, Zhang L, Dong G, Li Y, Xu R, Zhang B, Huang X, Li N, Wang Y, Qian Q, Li Y (2020) Control of Grain Size and Weight by the GSK2-LARGE1/OML4 Pathway in Rice. Plant Cell 32:1905-1918

Ma M, Zhao H, Li Z, Hu S, Song W, Liu X (2016) TaCYP78A5 regulates seed size in wheat (Triticum aestivum). J Exp Bot 67:1397-1410

Mao P, Duan M, Wei C, Li Y (2007) WRKY62 transcription factor acts downstream of cytosolic NPR1 and negatively regulates jasmonate-responsive gene expression. Plant Cell Physiol 48:833-842

Miller C, Wells R, McKenzie N, Trick M, Ball J, Fatihi A, Dubreucq B, Chardot T, Lepiniec L, Bevan MW (2019) Variation in Expression of the HECT E3 Ligase UPL3 Modulates LEC2 Levels, Seed Size, and Crop Yields in Brassica napus. Plant Cell 31:2370-2385

Page $9 / 22$ 
Moon J, Parry G, Estelle M (2004) The ubiquitin-proteasome pathway and plant development. Plant Cell 16:3181-3195

Moran CN, Halliday KJ (2010) Fruit development: new directions for an old pathway. Curr Biol 20:R1081-1083

Müller B, Fastner A, Karmann J, Mansch V, Hoffmann T, Schwab W, Suter-Grotemeyer M, Rentsch D, Truernit E, Ladwig F, Bleckmann A, Dresselhaus T, Hammes Ulrich Z (2015) Amino Acid Export in Developing Arabidopsis Seeds Depends on UmamiT Facilitators. Current Biology 25:3126-3131

Nguyen NH, Nguyen CTT, Jung C, Cheong JJ (2019) AtMYB44 suppresses transcription of the late embryogenesis abundant protein gene AtLEA4-5. Biochem Biophys Res Commun 511:931-934

Oh K, Matsumoto T, Yamagami A, Hoshi T, Nakano T, Yoshizawa Y (2015) Fenarimol, a Pyrimidine-Type Fungicide, Inhibits Brassinosteroid Biosynthesis. Int J Mol Sci 16:17273-17288

Ohashi-Ito K, Iwamoto K, Nagashima Y, Kojima M, Sakakibara H, Fukuda H (2019) A Positive Feedback Loop Comprising LHW-TM05 and Local Auxin Biosynthesis Regulates Initial Vascular Development in Arabidopsis Roots. Plant and Cell Physiology 60:2684-2691

Oshima Y, Mitsuda N (2013) The MIXTA-like transcription factor MYB16 is a major regulator of cuticle formation in vegetative organs. Plant Signal Behav 8:e26826

Raboanatahiry N, Chao H, Dalin H, Pu S, Yan W, Yu L, Wang B, Li M (2018) QTL Alignment for Seed Yield and Yield Related Traits in Brassica napus. Frontiers in Plant Science 9:1127

Raxwal VK, Simpson CG, Gloggnitzer J, Entinze JC, Guo W, Zhang R, Brown JWS, Riha K (2020) Nonsense-Mediated RNA Decay Factor UPF1 Is Critical for Posttranscriptional and Translational Gene Regulation in Arabidopsis. Plant Cell 32:2725-2741

Riehs-Kearnan N, Gloggnitzer J, Dekrout B, Jonak C, Riha K (2012) Aberrant growth and lethality of Arabidopsis deficient in nonsense-mediated RNA decay factors is caused by autoimmune-like response. Nucleic Acids Res 40:5615-5624

Sampedro J, Gianzo C, Iglesias N, Guitian E, Revilla G, Zarra I (2012) AtBGAL10 is the main xyloglucan $\beta$-galactosidase in Arabidopsis, and its absence results in unusual xyloglucan subunits and growth defects. Plant Physiol 158:1146-1157

Schommer C, Debernardi JM, Bresso EG, Rodriguez RE, Palatnik JF (2014) Repression of cell proliferation by miR319-regulated TCP4. Mol Plant 7:1533-1544

Sestili F, Pagliarello R, Zega A, Saletti R, Pucci A, Botticella E, Masci S, Tundo S, Moscetti I, Foti S, Lafiandra D (2019) Enhancing grain size in durum wheat using RNAi to knockdown GW2 genes. Theor Appl Genet 132:419-429

Shi L, Song J, Guo C, Wang B, Guan Z, Yang P, Chen X, Zhang Q, King GJ, Wang J, Liu K (2019) A CACTA-like transposable element in the upstream region of BnaA9.CYP78A9 acts as an enhancer to increase silique length and seed weight in rapeseed. Plant J 98:524-539

Shin R, Burch AY, Huppert KA, Tiwari SB, Murphy AS, Guilfoyle TJ, Schachtman DP (2007) The Arabidopsis transcription factor MYB77 modulates auxin signal transduction. Plant Cell 19:2440-2453

Simmonds J, Scott P, Brinton J, Mestre TC, Bush M, Del Blanco A, Dubcovsky J, Uauy C (2016) A splice acceptor site mutation in TaGW2-A1 increases thousand grain weight in tetraploid and hexaploid wheat through wider and longer grains. Theor Appl Genet 129:1099-1112

Song JM, Guan Z, Hu J, Guo C, Yang Z, Wang S, Liu D, Wang B, Lu S, Zhou R, Xie WZ, Cheng Y, Zhang Y, Liu K, Yang QY, Chen LL, Guo L (2020) Eight high-quality genomes reveal pan-genome architecture and ecotype differentiation of Brassica napus. Nat Plants 6:34-45

Song W-m, Cheng Z-h, Guo X-t, Yu C-y, Wang H-h, Wang J, Li B, Zhang H-x, Bao Y (2019) Overexpression of NHL6 affects seed production in transgenic Arabidopsis plants. Plant Growth Regulation 88:41-47

Staswick PE, Serban B, Rowe M, Tiryaki I, Maldonado MT, Maldonado MC, Suza W (2005) Characterization of an Arabidopsis enzyme family that conjugates amino acids to indole-3-acetic acid. Plant Cell 17:616-627

Sun L, Wang X, Yu K, Li W, Peng Q, Chen F, Zhang W, Fu S, Xiong D, Chu P, Guan R, Zhang J (2018) Mapping of QTLs controlling seed weight and seed-shape traits in Brassica napus L. using a high-density SNP map. Euphytica 214:228

Takahashi I, Kojima S, Sakaguchi N, Umeda-Hara C, Umeda M (2010) Two Arabidopsis cyclin A3s possess G1 cyclin-like features. Plant Cell Rep 29:307-315

Takubo E, Kobayashi M, Hirai S, Aoi Y, Ge C, Dai X, Fukui K, Hayashi KI, Zhao Y, Kasahara H (2020) Role of Arabidopsis INDOLE-3-ACETIC ACID CARBOXYL METHYLTRANSFERASE 1 in auxin metabolism. Biochem Biophys Res Commun 527:1033-1038

Page $10 / 22$ 
Taleski M, Chapman K, Imin N, Djordjevic MA, Groszmann M (2020) The Peptide Hormone Receptor CEPR1 Functions in the Reproductive Tissue to Control Seed Size and Yield. Plant Physiol 183:620-636

Tang S, Zhao H, Lu S, Yu L, Zhang G, Zhang Y, Yang QY, Zhou Y, Wang X, Ma W, Xie W, Guo L (2020) Genome- and transcriptome-wide association studies provide insights into the genetic basis of natural variation of seed oil content in Brassica napus. Mol Plant

USDA ERS (2020) https://www.ers.usda.gov/data-products/oil-cropsyearbook/

Wang H, Yan M, Xiong M, Wang P, Liu Y, Xin Q, Wan L, Yang G, Hong D (2020a) Genetic dissection of thousand-seed weight and fine mapping of cqSW.A03-2 via linkage and association analysis in rapeseed (Brassica napus L.). Theor Appl Genet 133:1321-1335

Wang J, Wang R, Mao X, Zhang J, Liu Y, Xie Q, Yang X, Chang X, Li C, Zhang X, Jing R (2020b) RING finger ubiquitin E3 ligase gene TaSDIR1-4A contributes to grain size in common wheat. J Exp Bot

Wang JL, Tang MQ, Chen S, Zheng XF, Mo HX, Li SJ, Wang Z, Zhu KM, Ding LN, Liu SY, Li YH, Tan XL (2017) Down-regulation of BnDA1, whose gene locus is associated with the seeds weight, improves the seeds weight and organ size in Brassica napus. Plant Biotechnol J 15:1024-1033

Wang L, Lu Q, Wen X, Lu C (2015) Enhanced Sucrose Loading Improves Rice Yield by Increasing Grain Size. Plant Physiol 169:2848-2862

Wang W, Simmonds J, Pan Q, Davidson D, He F, Battal A, Akhunova A, Trick HN, Uauy C, Akhunov E (2018) Gene editing and mutagenesis reveal intercultivar differences and additivity in the contribution of TaGW2 homoeologues to grain size and weight in wheat. Theor Appl Genet 131:2463-2475

Wang XC, Wu J, Guan ML, Zhao CH, Geng P, Zhao Q (2020c) Arabidopsis MYB4 plays dual roles in flavonoid biosynthesis. Plant J 101:637-652

Xia T, Li N, Dumenil J, Li J, Kamenski A, Bevan MW, Gao F, Li Y (2013) The ubiquitin receptor DA1 interacts with the E3 ubiquitin ligase DA2 to regulate seed and organ size in Arabidopsis. Plant Cell 25:3347-3359

Xie G, Li Z, Ran Q, Wang H, Zhang J (2018) Over-expression of mutated ZmDA1 or ZmDAR1 gene improves maize kernel yield by enhancing starch synthesis. Plant Biotechnol J 16:234-244

Xu FQ, Xue HW (2019) The ubiquitin-proteasome system in plant responses to environments. Plant Cell Environ 42:2931-2944

Xu R, Duan P, Yu H, Zhou Z, Zhang B, Wang R, Li J, Zhang G, Zhuang S, Lyu J, Li N, Chai T, Tian Z, Yao S, Li Y (2018) Control of Grain Size and Weight by the OsMKKK10-OsMKK4-OsMAPK6 Signaling Pathway in Rice. Mol Plant 11:860-873

Yang B, Wendrich JR, De Rybel B, Weijers D, Xue HW (2019) Rice microtubule-associated protein IQ67-DOMAIN14 regulates grain shape by modulating microtubule cytoskeleton dynamics. Plant Biotechnol J 18:1141-1152

Yang F, Song Y, Yang H, Liu Z, Zhu G, Yang Y (2014) An auxin-responsive endogenous peptide regulates root development in Arabidopsis. J Integr Plant Biol 56:635-647

Yang L, Sun Q, Wang Y, Chan Z (2021) Global transcriptomic network of melatonin regulated root growth in Arabidopsis. Gene 764:145082

Yang Y, Zhang L, Chen P, Liang T, Li X, Liu H (2020) UV-B photoreceptor UVR8 interacts with MYB73/MYB77 to regulate auxin responses and lateral root development. EMBO J 39:e101928

Yu SG, Kim JH, Cho NH, Oh TR, Kim WT (2020a) Arabidopsis RING E3 ubiquitin ligase JUL1 participates in ABA-mediated microtubule depolymerization, stomatal closure, and tolerance response to drought stress. Plant J 103:824-842

Yu SX, Zhou LW, Hu LQ, Jiang YT, Zhang YJ, Feng SL, Jiao Y, Xu L, Lin WH (2020b) Asynchrony of ovule primordia initiation in Arabidopsis. Development 147

Zhang L, Li S, Chen L, Yang G (2012) Identification and mapping of a major dominant quantitative trait locus controlling seeds per silique as a single Mendelian factor in Brassica napus L. Theor Appl Genet 125:695-705

Zhang L, Yang G, Liu P, Hong D, Li S, He Q (2011) Genetic and correlation analysis of silique-traits in Brassica napus L. by quantitative trait locus mapping. Theor Appl Genet 122:21-31

Zhang Y, Li D, Zhang D, Zhao X, Cao X, Dong L, Liu J, Chen K, Zhang H, Gao C, Wang D (2018) Analysis of the functions of TaGW2 homoeologs in wheat grain weight and protein content traits. Plant J 94:857-866

Zhang YY, Li Y, Gao T, Zhu H, Wang DJ, Zhang HW, Ning YS, Liu LJ, Wu YR, Chu CC, Guo HS, Xie Q (2008) Arabidopsis SDIR1 enhances drought tolerance in crop plants. Biosci Biotechnol Biochem 72:2251-2254

Page $11 / 22$ 
Zhao M, Gu Y, He L, Chen Q, He C (2015) Sequence and expression variations suggest an adaptive role for the DA1-like gene family in the evolution of soybeans. BMC Plant Biol 15:120

\section{Tables}

Table 1 Predicted genes within the 266-kb region and differences in sequence and expression levels 


\begin{tabular}{|c|c|c|c|c|}
\hline Gene & Ath_ID & $\mathrm{Seq}^{\mathrm{a}}$ & $\operatorname{Exp}^{b}$ & Function \\
\hline BnaC09G0547900ZS & null & D & NE & Ulp1 protease family protein \\
\hline BnaC09G0548000ZS & AT5G10770 & ND & ND & Eukaryotic aspartyl protease family protein \\
\hline BnaC09G0548100ZS & AT5G10760 & ND & $\mathrm{NE}$ & Eukaryotic aspartyl protease family protein \\
\hline BnaC09G0548200ZS & null & ND & $\mathrm{NE}$ & - \\
\hline BnaC09G0548300ZS & AT5G10770 & ND & $\mathrm{NE}$ & Eukaryotic aspartyl protease family protein \\
\hline BnaC09G0548400ZS & AT4G37490 & ND & ND & Cyclin-dependent protein kinase CYCB1 \\
\hline BnaC09G0548500ZS & AT5G10770 & ND & $\mathrm{NE}$ & Eukaryotic aspartyl protease family protein \\
\hline BnaC09G0548600ZS & null & ND & $\mathrm{NE}$ & - \\
\hline BnaC09G0548700ZS & AT5G10740 & D & ND & Protein phosphatase $2 \mathrm{C}$ family protein \\
\hline BnaC09G0548800ZS & AT5G10720 & ND & $\mathrm{NE}$ & member of Histidine Kinase \\
\hline BnaC09G0548900ZS & AT5G10700 & ND & ND & Peptidyl-tRNA hydrolase II (PTH2) family protein \\
\hline BnaC09G0549000ZS & AT5G10695 & ND & ND & - \\
\hline BnaC09G0549100ZS & AT5G10660 & ND & ND & calmodulin-binding protein-related \\
\hline BnaC09G0549200ZS & null & ND & $\mathrm{NE}$ & - \\
\hline BnaC09G0549300ZS & AT5G10650 & ND & ND & RING/U-box superfamily protein \\
\hline BnaC09G0549400ZS & AT4G32910 & ND & ND & Nuclear pore complex protein NUP85 \\
\hline BnaC09G0549500ZS & AT5G10625 & ND & $\mathrm{NE}$ & flowering-promoting factor-like protein \\
\hline BnaC09G0549600ZS & AT5G10620 & ND & ND & methyltransferases \\
\hline BnaC09G0549700ZS & AT5G19400 & ND & $\mathrm{NE}$ & Encodes SMG7 \\
\hline BnaC09G0549800ZS & AT5G17760 & ND & $\mathrm{NE}$ & P-loop containing nucleoside triphosphate hydrolases superfamily protein \\
\hline BnaC09G0549900ZS & AT5G17770 & ND & $\mathrm{NE}$ & Encodes NADH \\
\hline BnaC09G0550000ZS & AT1G15820 & ND & NE & Lhcb6 protein (Lhcb6), light harvesting complex of photosystem II. \\
\hline BnaC09G0550100ZS & null & ND & $\mathrm{NE}$ & - \\
\hline BnaC09G0550200ZS & null & ND & ND & - \\
\hline BnaC09G0550300ZS & AT5G09550 & ND & $\mathrm{NE}$ & GDP dissociation inhibitor family protein \\
\hline BnaC09G0550400ZS & AT2G42470 & ND & NE & TRAF-like family protein \\
\hline BnaC09G0550500ZS & null & ND & ND & - \\
\hline BnaC09G0550600ZS & AT5G10560 & ND & ND & Glycosyl hydrolase family protein \\
\hline BnaC09G0550700ZS & AT5G10560 & ND & ND & Glycosyl hydrolase family protein \\
\hline BnaC09G0550800ZS & AT5G05290 & ND & $\mathrm{NE}$ & Encodes an expansin \\
\hline BnaC09G0550900ZS & AT5G10650 & ND & ND & RING/U-box superfamily protein \\
\hline BnaC09G0551000ZS & AT5G10625 & ND & ND & flowering-promoting factor-like protein \\
\hline BnaC09G0551100ZS & AT5G10620 & ND & ND & methyltransferases \\
\hline BnaC09G0551200ZS & AT5G10610 & D & - & member of CYP81K \\
\hline BnaC09G0551300ZS & AT5G19400 & D & - & Encodes SMG7 \\
\hline BnaC09G0551400ZS & AT2G16360 & D & - & Ribosomal protein S25 family protein \\
\hline BnaC09G0551500ZS & AT5G10650 & D & - & RING/U-box superfamily protein \\
\hline BnaC09G0551600ZS & AT5G10650 & D & - & RING/U-box superfamily protein \\
\hline BnaC09G0551700ZS & AT5G10625 & D & - & flowering-promoting factor-like protein \\
\hline
\end{tabular}

a Sequence difference in the coding region between $\mathrm{HZ} 396$ and NIL(Y106). ND, no difference; D, difference.

Page $13 / 22$ 
${ }^{\mathrm{b}}$ Difference in expression levels between HZ396 and NIL(Y106). ND, no difference; NE, no expression; --, not clear.

Table 2. Candidate genes that may regulate seed size from DEGs.

Page $14 / 22$ 


\begin{tabular}{|c|c|c|c|c|c|c|}
\hline & $\log 2^{a}$ & P-adj & Ath-ID & Ath-name & Function & Refence \\
\hline \multicolumn{7}{|l|}{ Seed size or yield } \\
\hline BnaC04G0013000ZS & -2.00 & 0.0012 & AT2G46660 & CYP78A6/EOD3 & $\begin{array}{l}\text { Cytochrome P450 } \\
\text { CYP78A6 }\end{array}$ & $\begin{array}{l}\text { (Fang et al. } \\
2012 \text { ) }\end{array}$ \\
\hline BnaA05G0012500ZS & -1.26 & 0.0213 & AT2G46660 & & & \\
\hline BnaA09G0639400ZS & -1.10 & 0.0316 & AT1G13710 & CYP78A5/KLU & $\begin{array}{l}\text { Cytochrome P450 } \\
\text { CYP78A5 }\end{array}$ & $\begin{array}{l}\text { (Eriksson et } \\
\text { al. 2010; Ma } \\
\text { et al. 2016) }\end{array}$ \\
\hline BnaA02G0081400ZS & -1.24 & 0.0493 & AT3G16360 & AHP4 & HPT phosphotransmitter 4 & $\begin{array}{l}\text { (Hutchison } \\
\text { et al. 2006) }\end{array}$ \\
\hline BnaA10G0072400ZS & 1.25 & $\begin{array}{l}1.87 \mathrm{E}- \\
11\end{array}$ & AT5G49660 & CEPR1/XIP1 & $\begin{array}{l}\text { Leucine-rich repeat } \\
\text { transmembrane protein } \\
\text { kinase family protein }\end{array}$ & $\begin{array}{l}\text { (Taleski et } \\
\text { al. 2020) }\end{array}$ \\
\hline BnaC09G0322500ZS & 1.26 & $\begin{array}{l}4.25 \mathrm{E}- \\
11\end{array}$ & AT5G49660 & & & \\
\hline BnaA09G0459100ZS & -1.53 & $\begin{array}{l}1.08 \mathrm{E}- \\
09\end{array}$ & AT1G22710 & SUC2 & $\begin{array}{l}\text { Sucrose-proton symporter } \\
2\end{array}$ & $\begin{array}{l}\text { (Wang et al. } \\
\text { 2015) }\end{array}$ \\
\hline BnaA07G0121100ZS & -1.64 & $\begin{array}{l}8.27 \mathrm{E}- \\
07\end{array}$ & AT1G22710 & & & \\
\hline BnaC05G0166300ZS & 6.64 & $\begin{array}{l}4.68 \mathrm{E}- \\
273\end{array}$ & AT1G19640 & JMT & $\begin{array}{l}\text { Jasmonic acid carboxyl } \\
\text { methyltransferase }\end{array}$ & $\begin{array}{l}\text { (Cipollini } \\
\text { 2007; Kim } \\
\text { et al. 2009) }\end{array}$ \\
\hline \multicolumn{7}{|l|}{ Fruit size } \\
\hline BnaC05G0173200ZS & -1.23 & $\begin{array}{l}6.08 \mathrm{E}- \\
15\end{array}$ & AT1G20330 & SMT2 & Sterol methyltransferase 2 & $\begin{array}{l}\text { (Darnet et } \\
\text { al. 2020) }\end{array}$ \\
\hline BnaC05G0173100ZS & -1.21 & $\begin{array}{l}1.22 \mathrm{E}- \\
14\end{array}$ & AT1G20330 & & & \\
\hline BnaA03G0457400ZS & 1.77 & $\begin{array}{l}1.33 \mathrm{E}- \\
13\end{array}$ & AT4G20270 & BAM3 & $\begin{array}{l}\text { Leucine-rich receptor-like } \\
\text { protein kinase family } \\
\text { protein }\end{array}$ & $\begin{array}{l}\text { (DeYoung et } \\
\text { al. 2006) }\end{array}$ \\
\hline BnaA02G0006700ZS & 1.22 & $\begin{array}{l}3.17 \mathrm{E}- \\
10\end{array}$ & AT5G02030 & $\begin{array}{l}\text { RPL/BLH9/LSN } \\
\text { /PNY/VAN }\end{array}$ & $\begin{array}{l}\text { POX (plant homeobox) } \\
\text { family protein }\end{array}$ & $\begin{array}{l}\text { (Bencivenga } \\
\text { et al. 2016) }\end{array}$ \\
\hline BnaC09G0620200ZS & 2.00 & $\begin{array}{l}1.92 \mathrm{E}- \\
08\end{array}$ & AT5G02030 & & & \\
\hline BnaC03G0538400ZS & 3.52 & $\begin{array}{l}1.49 \mathrm{E}- \\
05\end{array}$ & AT5G63810 & BGAL10 & Beta-galactosidase 10 & $\begin{array}{l}\text { (Sampedro } \\
\text { et al. 2012) }\end{array}$ \\
\hline BnaC07G0207700ZS & -1.41 & 0.0043 & AT5G67110 & ALC & $\begin{array}{l}\text { Basic helix-loop-helix } \\
\text { (bHLH) DNA-binding } \\
\text { superfamily protein }\end{array}$ & $\begin{array}{l}\text { (Moran and } \\
\text { Halliday } \\
\text { 2010) }\end{array}$ \\
\hline \multicolumn{7}{|c|}{ Cell proliferation or expansion } \\
\hline BnaA06G0110200ZS & 1.46 & $\begin{array}{l}2.59 \mathrm{E}- \\
08\end{array}$ & AT1G16330 & СYСВ3;1 & $\begin{array}{l}\text { Core cell cycle genes, } \\
\text { Putative cyclin-B3-1 }\end{array}$ & $\begin{array}{l}\text { (Bulankova } \\
\text { et al. 2013) }\end{array}$ \\
\hline BnaA06G0192600ZS & -6.69 & $\begin{array}{l}1.20 \mathrm{E}- \\
07\end{array}$ & AT1G76540 & CDKB2.1 & $\begin{array}{l}\text { Cyclin-dependent kinase } \\
\text { B2-1 }\end{array}$ & $\begin{array}{l}\text { (Chen et al. } \\
\text { 2020) }\end{array}$ \\
\hline BnaA06G0192500ZS & -7.53 & $\begin{array}{l}2.74 \mathrm{E}- \\
07\end{array}$ & AT1G76540 & & & \\
\hline BnaA07G0368600ZS & -4.99 & $\begin{array}{l}4.09 \mathrm{E}- \\
05\end{array}$ & AT1G77390 & CYCA1/DYP/TAM & Cyclin-A1-2 & $\begin{array}{l}\text { (Jha et al. } \\
\text { 2014) }\end{array}$ \\
\hline BnaC02G0504800ZS & -6.41 & $\begin{array}{l}6.13 \mathrm{E}- \\
05\end{array}$ & AT4G27700 & - & $\begin{array}{l}\text { Rhodanese/Cell cycle } \\
\text { control phosphatase } \\
\text { superfamily protein }\end{array}$ & - \\
\hline BnaC03G0726900ZS & -1.71 & 0.0034 & AT4G27700 & & & \\
\hline BnaC09G0529100ZS & -8.64 & $\begin{array}{l}4.90 \mathrm{E}- \\
10\end{array}$ & AT5G43080 & СYСАЗ;1 & Putative cyclin-A3-1 & $\begin{array}{l}\text { (Takahashi } \\
\text { et al. 2010) }\end{array}$ \\
\hline
\end{tabular}




\begin{tabular}{|c|c|c|c|c|c|c|}
\hline BnaA05G0050700ZS & 3.38 & $\begin{array}{l}1.46 \mathrm{E}- \\
242\end{array}$ & AT2G40360 & ATPEP1/BOP1 & $\begin{array}{l}\text { Transducin/WD40 repeat- } \\
\text { like superfamily protein }\end{array}$ & $\begin{array}{l}\text { (Carvalho et } \\
\text { al. 2016) }\end{array}$ \\
\hline BnaA01G0426800ZS & -3.27 & $\begin{array}{l}1.63 \mathrm{E}- \\
22\end{array}$ & AT2G17420 & NTRA/NTR2 & $\begin{array}{l}\text { NADPH-dependent } \\
\text { thioredoxin reductase A }\end{array}$ & $\begin{array}{l}\text { (Bashandy } \\
\text { et al. 2011) }\end{array}$ \\
\hline BnaA01G0301700ZS & -3.24 & $\begin{array}{l}3.43 \mathrm{E}- \\
21\end{array}$ & AT2G17420 & & & \\
\hline BnaA03G0410200ZS & 1.17 & $\begin{array}{l}1.73 \mathrm{E}- \\
06\end{array}$ & AT5G61480 & $\mathrm{PXY} / \mathrm{TDR}$ & $\begin{array}{l}\text { Leucine-rich repeat protein } \\
\text { kinase family protein }\end{array}$ & $\begin{array}{l}\text { (Etchells et } \\
\text { al. 2012) }\end{array}$ \\
\hline BnaC07G0382400ZS & 1.36 & $\begin{array}{l}2.94 \mathrm{E}- \\
06\end{array}$ & AT5G61480 & & & \\
\hline \multicolumn{7}{|l|}{ Phytohormone signaling } \\
\hline BnaA07G0137400ZS & -3.96 & $\begin{array}{l}1.16 \mathrm{E}- \\
19\end{array}$ & AT1G19840 & SAUR53 & $\begin{array}{l}\text { SAUR-like auxin- } \\
\text { responsive protein family }\end{array}$ & $\begin{array}{l}\text { (Kathare et } \\
\text { al. 2018) }\end{array}$ \\
\hline BnaC07G0200000ZS & -1.66 & $\begin{array}{l}2.99 \mathrm{E}- \\
08\end{array}$ & AT1G19840 & & & \\
\hline BnaC05G0168800ZS & 9.03 & $\begin{array}{l}1.59 \mathrm{E}- \\
11\end{array}$ & AT1G19850 & MP/ARF5/IAA24 & $\begin{array}{l}\text { Transcriptional factor B3 } \\
\text { family protein / auxin- } \\
\text { responsive factor } \\
\text { AUX/IAA-like protein }\end{array}$ & $\begin{array}{l}\text { (Cucinotta } \\
\text { et al. 2020) }\end{array}$ \\
\hline Bnascaffold0026G0000500ZS & -1.71 & 0.0182 & AT1G35520 & ARF15 & Auxin response factor 15 & - \\
\hline BnaC06G0353300ZS & -1.53 & 0.0020 & AT1G68810 & ABS5/T5L1 & $\begin{array}{l}\text { Basic helix-loop-helix } \\
\text { (bHLH) DNA-binding } \\
\text { superfamily protein }\end{array}$ & $\begin{array}{l}\text { (Ohashi-lto } \\
\text { et al. 2019) }\end{array}$ \\
\hline BnaA07G0304700ZS & -1.63 & 0.0201 & AT1G68810 & & & \\
\hline BnaA07G0339400ZS & -1.55 & 0.0003 & AT1G73590 & PIN1 & $\begin{array}{l}\text { Auxin efflux carrier family } \\
\text { protein }\end{array}$ & $\begin{array}{l}\text { (Yu et al. } \\
2020)\end{array}$ \\
\hline BnaA05G0002400ZS & -1.16 & $\begin{array}{l}3.09 \mathrm{E}- \\
22\end{array}$ & AT2G47750 & GH3.9 & $\begin{array}{l}\text { Putative indole-3-acetic } \\
\text { acid-amido synthetase } \\
\text { GH3.9 }\end{array}$ & $\begin{array}{l}\text { (Staswick et } \\
\text { al. 2005) }\end{array}$ \\
\hline BnaC04G0002500ZS & -1.25 & $\begin{array}{l}1.72 \mathrm{E}- \\
07\end{array}$ & AT2G47750 & & & \\
\hline BnaC03G0492700ZS & -1.62 & 0.0485 & AT4G03400 & DFL2 & $\begin{array}{l}\text { Auxin-responsive GH3 } \\
\text { family protein }\end{array}$ & - \\
\hline BnaA01G0015100ZS & -1.62 & 0.0003 & AT4G37390 & BRU6/AUR3/GH3.2/YDK1 & $\begin{array}{l}\text { Auxin-responsive GH3 } \\
\text { family protein }\end{array}$ & $\begin{array}{l}\text { (Yang et al. } \\
\text { 2014) }\end{array}$ \\
\hline BnaA10G0113300ZS & -1.32 & $\begin{array}{l}1.23 \mathrm{E}- \\
05\end{array}$ & AT5G55250 & IAMT1 & $\begin{array}{l}\text { IAA } \\
\text { carboxylmethyltransferase } \\
1\end{array}$ & $\begin{array}{l}\text { (Takubo et } \\
\text { al. 2020) }\end{array}$ \\
\hline BnaA01G0357900ZS & 3.07 & $\begin{array}{l}9.34 \mathrm{E}- \\
06\end{array}$ & AT3G13730 & CYP90D1 & $\begin{array}{l}\text { Cytochrome P450 } \\
\text { CYP90D1, BR synthesis }\end{array}$ & $\begin{array}{l}\text { (Oh et al. } \\
2015)\end{array}$ \\
\hline BnaA05G0414100ZS & 1.98 & 0.0167 & AT3G13730 & & & \\
\hline BnaC05G0466200ZS & 1.51 & 0.0206 & AT3G13730 & & & \\
\hline \multicolumn{7}{|l|}{ Transcriptional regulators } \\
\hline BnaC05G0004900ZS & -1.21 & $\begin{array}{l}8.39 \mathrm{E}- \\
09\end{array}$ & AT1G01720 & ATAF1/NAC2 & $\begin{array}{l}\text { NAC (No Apical Meristem) } \\
\text { domain transcriptional } \\
\text { regulator superfamily } \\
\text { protein }\end{array}$ & $\begin{array}{l}\text { (Yang et al. } \\
\text { 2021) }\end{array}$ \\
\hline BnaC01G0435000ZS & 1.21 & 0.0007 & AT3G15030 & TCP4/MEE35 & $\begin{array}{l}\text { TCP family transcription } \\
\text { factor } 4\end{array}$ & $\begin{array}{l}\text { (Schommer } \\
\text { et al. 2014) }\end{array}$ \\
\hline BnaC05G0452400ZS & 1.07 & 0.0016 & AT3G15030 & & & \\
\hline BnaA03G0414300ZS & -1.09 & $\begin{array}{l}5.24 \mathrm{E}- \\
07\end{array}$ & AT3G50060 & MYB77 & Myb domain protein 77 & $\begin{array}{l}\text { (Shin et al. } \\
\text { 2007) }\end{array}$ \\
\hline Bnascaffold0025G0032600ZS & -1.07 & $\begin{array}{l}7.85 \mathrm{E}- \\
06\end{array}$ & AT3G50060 & & & \\
\hline BnaA09G0019700ZS & -1.18 & 0.0383 & AT4G01500 & NGA4 & $\begin{array}{l}\text { AP2/B3-like } \\
\text { transcriptional factor }\end{array}$ & $\begin{array}{l}\text { (Lee et al. } \\
2015)\end{array}$ \\
\hline
\end{tabular}




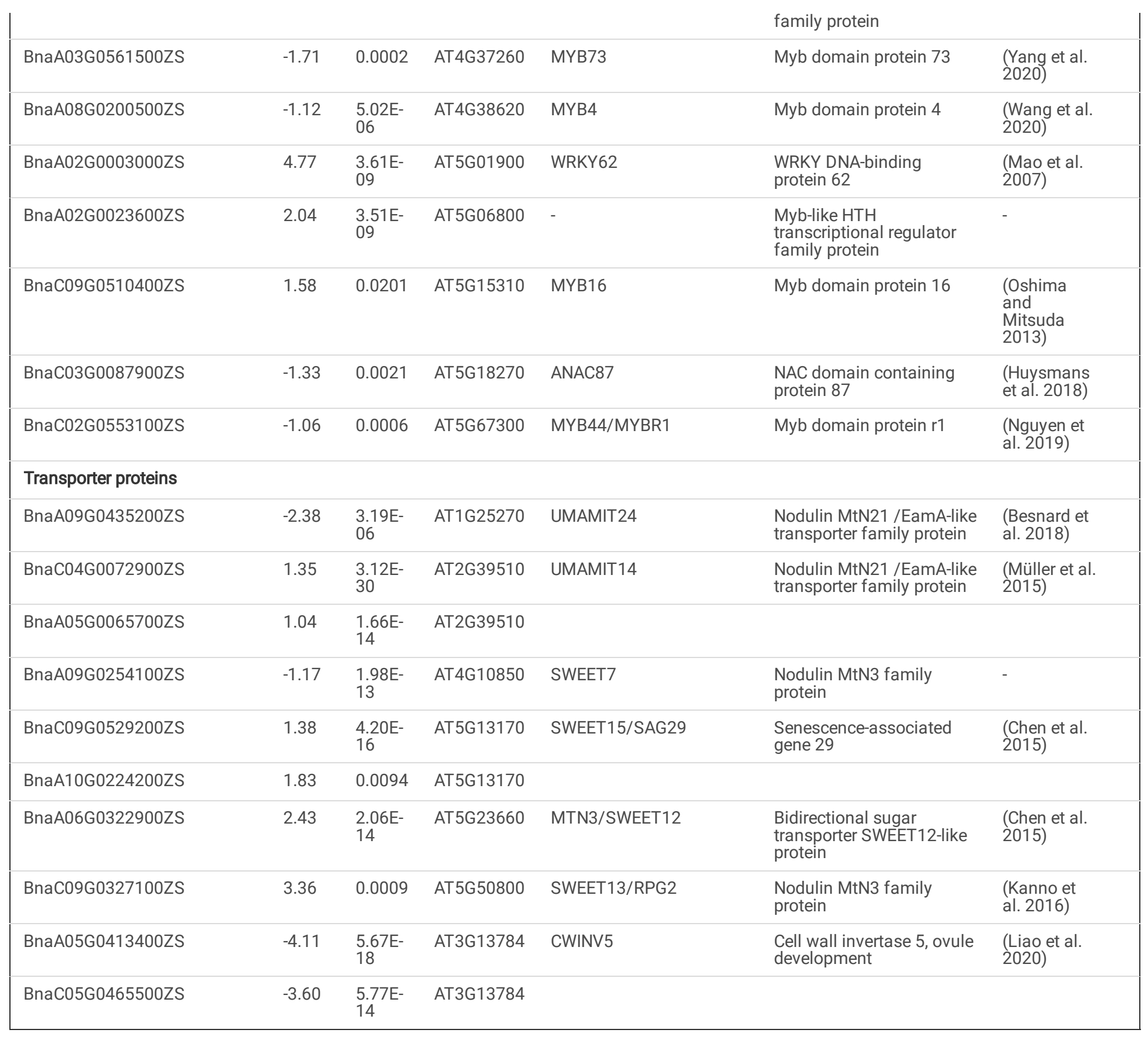

a This value represents the $\log _{2}$ FoldChange. Negative value means higher expression level in NIL(Y106).

\section{Figures}


a

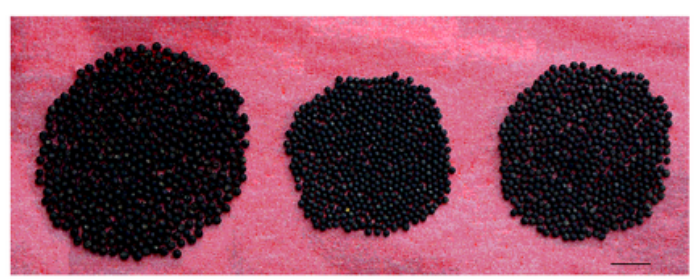

HZ396

NIL(Y106)

Y106

b

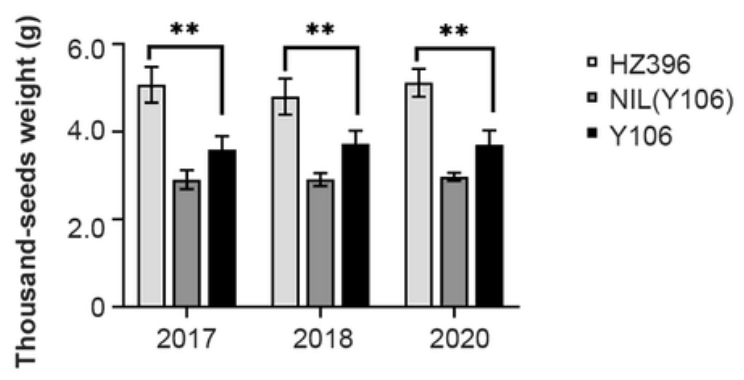

C

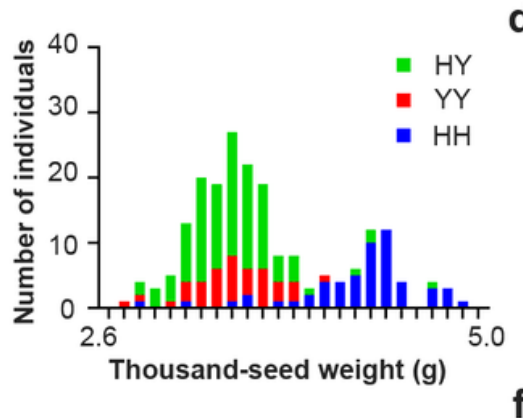

e

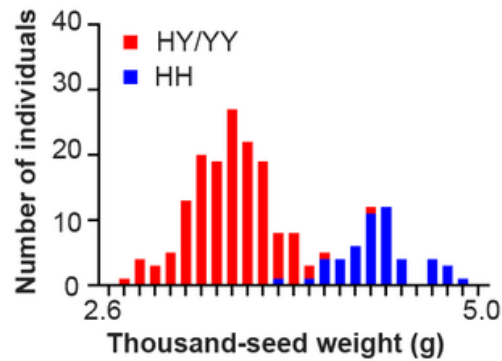

d

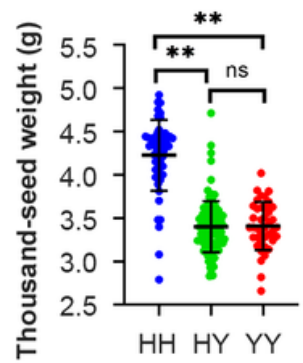

f

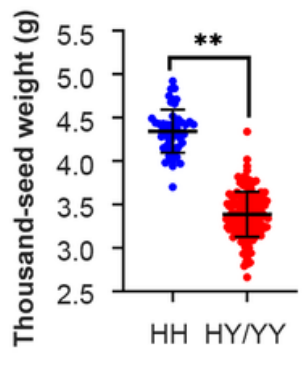

\section{Figure 1}

Variation for thousand-seed weight (TSW) in the BC3F2 population and parents. a Seeds of HZ396, Y106, and NIL(Y106) show considerable variation in size. $\mathrm{N}=500$ seeds, bar = $5 \mathrm{~mm}$. b Thousand-seed weight (TSW) of HZ396, Y106, and NIL(Y106) over 3 years. Error bars represent standard deviation; ${ }^{* *} \mathrm{P}<0.01$ (one-way ANOVA). $c-f$ Distributions $(c, e)$ and scatter plots $(d, f)$ of TSW in group A as a function of the genotypes at markers SCC9-136 (c, d) and STC9-164 (e, f). Different colors represent different genotypes based on marker STC9-164. HH, homozygous for the HZ396 allele; YY/HY, heterozygous genotype or homozygous for the Y106 allele. Error bars represent standard deviation; **P < 0.01 (one-way ANOVA). 


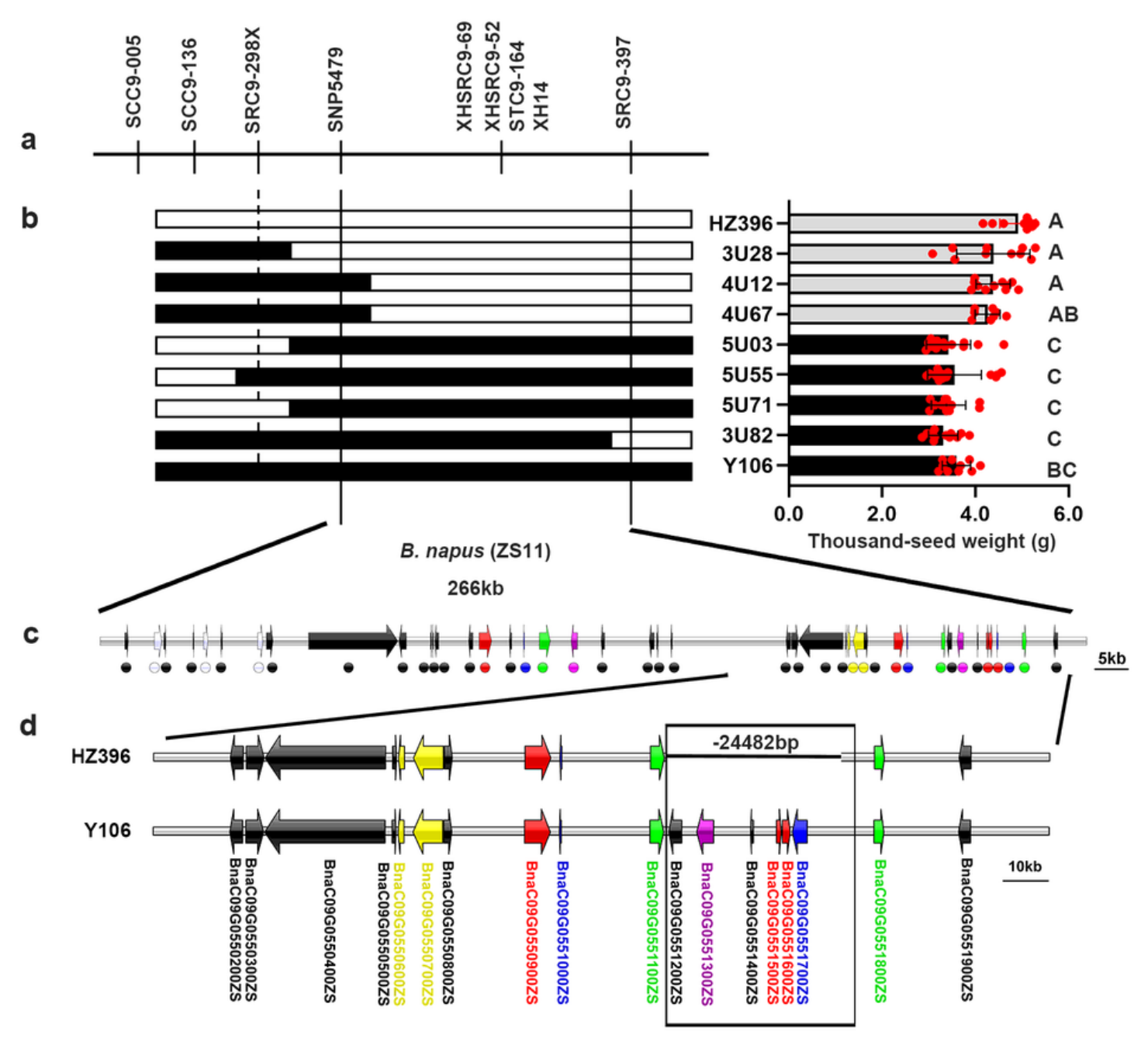

Figure 2

Fine-mapping of qSW.C9. a Distribution of markers within the mapping interval. b Recombination summary for seven representative recombinants and their parents (left) and their associated TSW phenotypes (right). Light gray bands represent regions that are homozygous for the HZ396 genotype; black bands represent regions that are homozygous or heterozygous for the Y106 allele. TSW data are shown as mean \pm SD; different letters next the bars indicate significant differences, according to Bonferroni's multiple-comparisons test $(P<0.01)$. c Genomic organization of the mapping interval. Each arrow and circle represents an annotated gene; drawn to scale. Genes shown as a circle of the same color are homologous. Bar $=5 \mathrm{~kb}$. d Schematic diagram of the major polymorphism between HZ396 and Y106. The deletion of 24,482 bp and gene names from the ZS11 reference genome are shown. Bar $=10 \mathrm{~kb}$. 
a

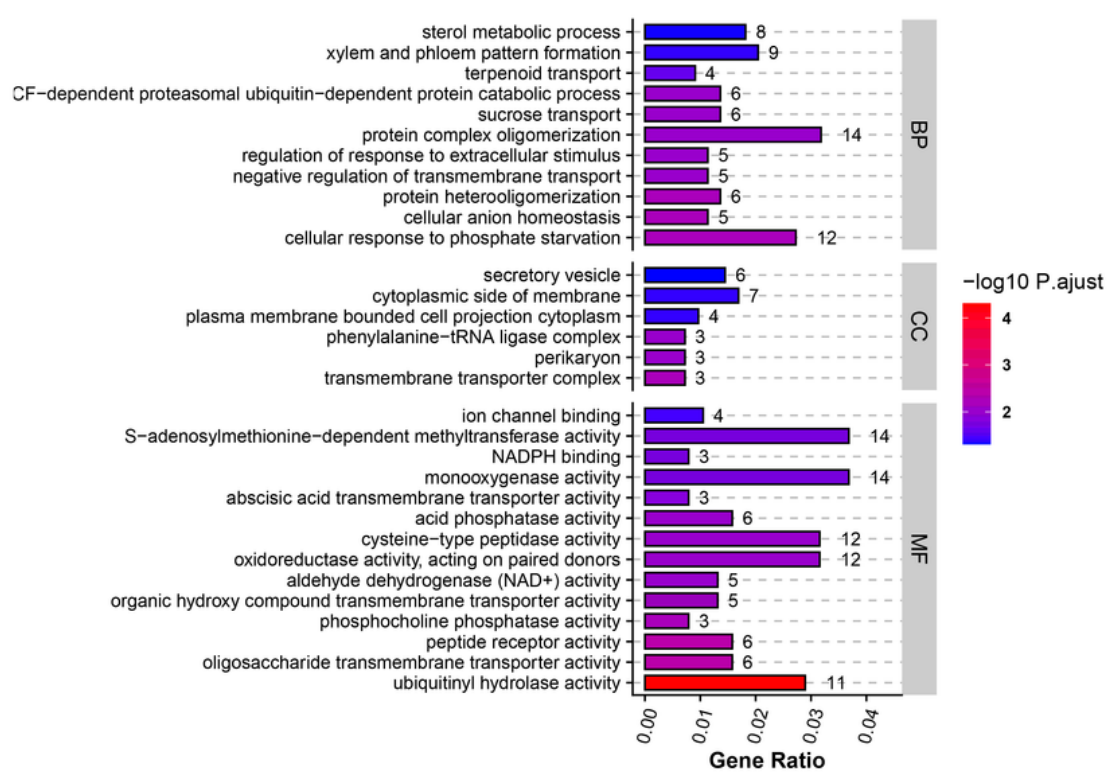

b

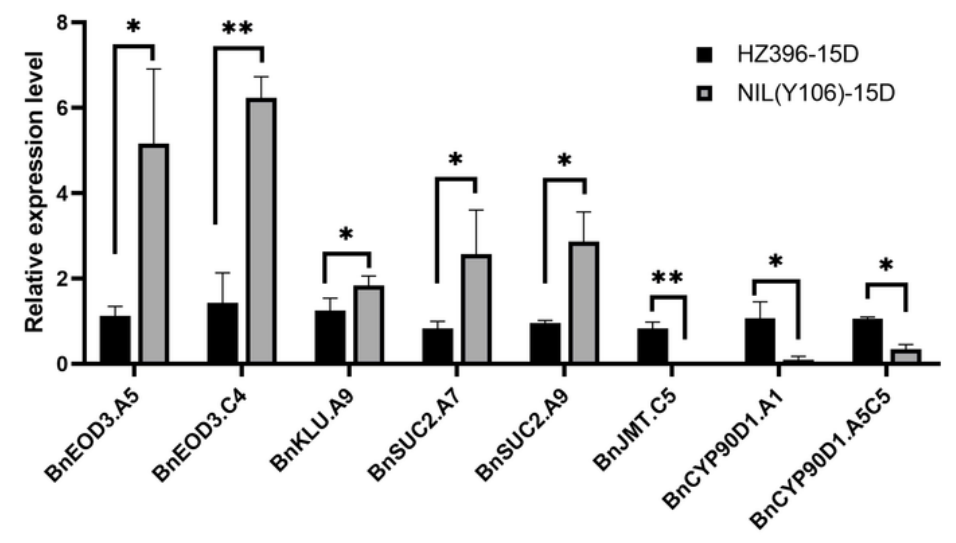

\section{Figure 3}

Analysis of differentially expressed genes (DEGs) between HZ396 and NIL(Y106). a Non-duplicate Gene Ontology (GO) terms for DEGs. BP, biological process; CC, cellular compartment; MF, molecular function. b Relative expression levels of select genes involved in the regulation of seed development, highlighted from enriched GO terms. The first replicate for HZ396 was used as a control. 
a

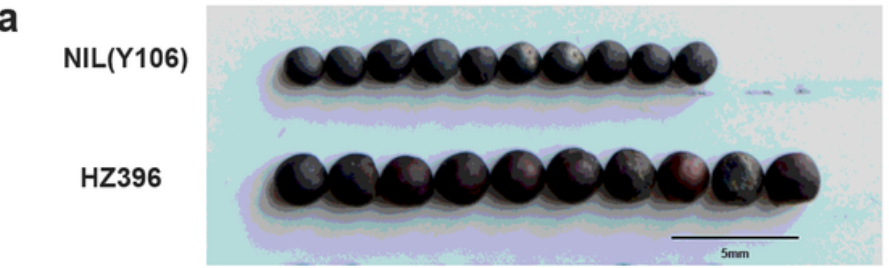

b

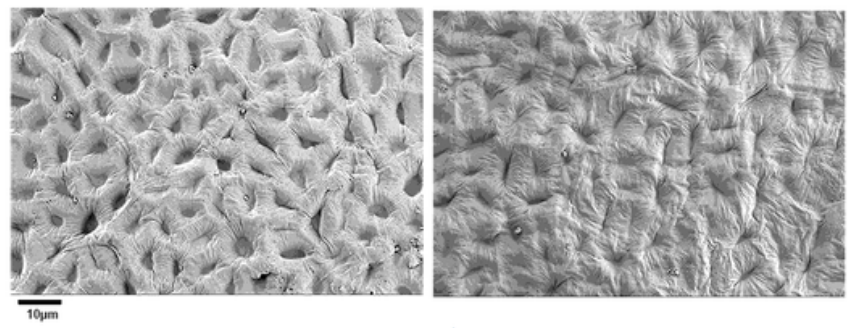

e

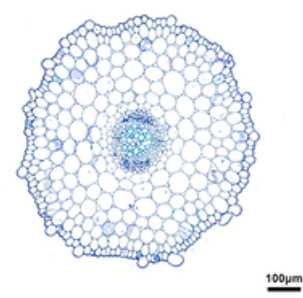

NIL(Y106)
C

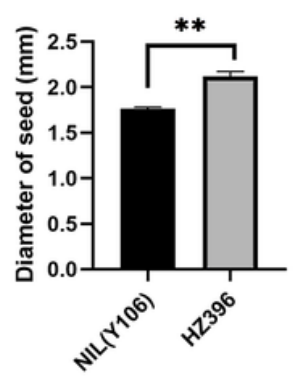

$\mathbf{f}$

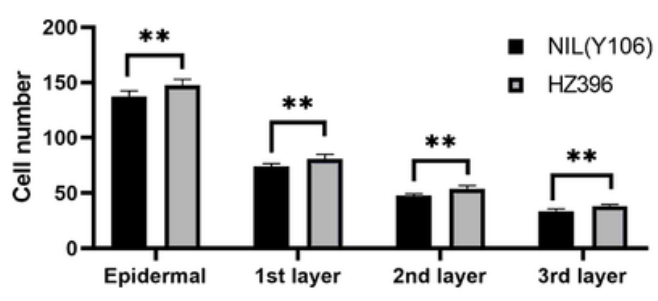

g

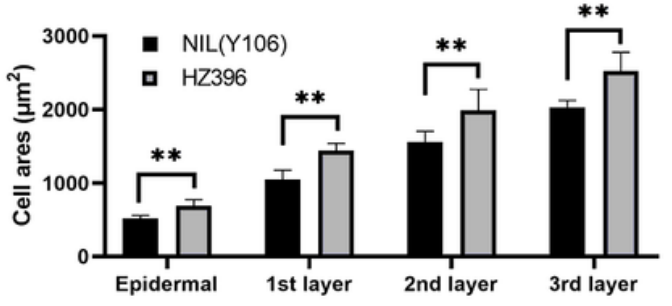

Figure 4

HZ396 and NIL(Y106) have distinct seed sizes, cell sizes, and cell numbers. a Seeds of HZ396 are much bigger than those of NIL(Y106). $\mathrm{N}=10$, bar $=$ $5 \mathrm{~mm}$. b Representative image of seed coat cells of mature seeds. Bar $=10 \mu \mathrm{m}$. c Mean seed diameter for HZ396 and NIL(Y106). d Mean cell area for the seed coat in HZ396 and NIL(Y106). e Cell morphology in hypocotyl cross sections. Bars $=100 \mu \mathrm{m}$. $\mathrm{f}$ Mean cell number in various cell types for $\mathrm{HZ396}$ and NIL(Y106). The epidermal cells and the outermost three layers of cells in the same section were counted. $\mathrm{g}$ Mean cell areas in various cell types for HZ396 and $\mathrm{NIL}(\mathrm{Y} 106)$. ${ }^{*} \mathrm{P}<0.05$, **P $<0.01$ (one-way ANOVA). All data are shown as means \pm SD.

a

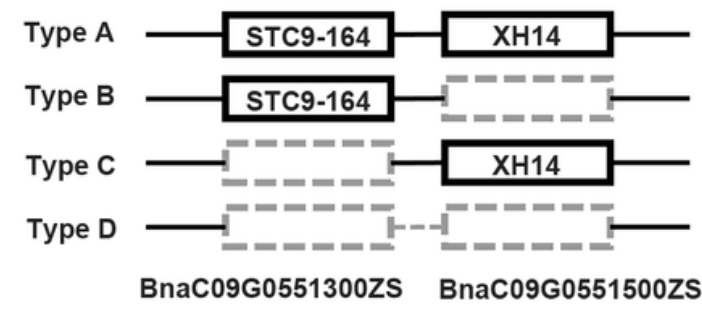

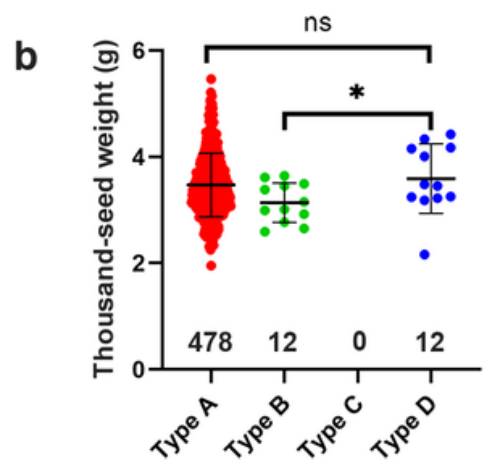

\section{Figure 5}

Haplotype analysis in natural populations for two genes deleted in HZ396. a Schematic diagram of different haplotypes, as defined by the genotyping results at markers XH14 and STC9-164. b Scatterplot of TSW for the different haplotype groups defined in (a). The numbers above the $\mathrm{x}$ axis are the number of accessions per haplotype group. Data are also shown as mean $\pm \mathrm{SD}$; *P $<0.05$ (one-way ANOVA).

\section{Supplementary Files}

This is a list of supplementary files associated with this preprint. Click to download. 
- FigS1.tif

- FigS2.tif

- FigS3.tif

- FigS4.tif

- FigS5.tif

- FigS6.tif

- FigS7.tif

- Table.S1.docx

- Table.S2.xIsx

- Table.S3.docx

- Table.S4.docx 